Georgia State University

ScholarWorks @ Georgia State University

2014

\title{
An Integrative Common Liabilities Model for the Comorbidity of Substance Use Disorders with Externalizing and Internalizing Disorders
}

\author{
Erin Tully \\ Georgia State University, etully2@gsu.edu \\ William G. Iacono \\ University of Minnesota - Twin Cities, wiacono@tfs.psych.umn.edu
}

Follow this and additional works at: https://scholarworks.gsu.edu/psych_facpub

Part of the Psychology Commons

\section{Recommended Citation}

Tully, Erin and lacono, William G., "An Integrative Common Liabilities Model for the Comorbidity of Substance Use Disorders with Externalizing and Internalizing Disorders" (2014). Psychology Faculty Publications. 145.

https://scholarworks.gsu.edu/psych_facpub/145

This Article is brought to you for free and open access by the Department of Psychology at ScholarWorks @ Georgia State University. It has been accepted for inclusion in Psychology Faculty Publications by an authorized administrator of ScholarWorks @ Georgia State University. For more information, please contact scholarworks@gsu.edu. 
An Integrative Common Liabilities Model for the Comorbidity of Substance Use Disorders with Externalizing and Internalizing Disorders

Erin C. Tully

William G. Iacono

University of Minnesota

\begin{abstract}
This paper presents an integrative research-derived model to explain comorbidity among SUDs, externalizing disorders, and internalizing disorders. This hierarchical model is based on phenotypic covariance among the disorders and latent common genetic liability. At the highest level of the hierarchy, general genetically-influenced biological dispositions to negative emotionality and behavioral disinhibition each give rise to spectra of related personality traits, cognitive processes, behavioral tendencies, and psychopathology that account for the pattern of co-occurrence among mental disorders. At the lowest level of the hierarchy, disorder-specific genetic and environmental effects explain the presence of some and not other disorders associated with a given general liability. Interplay between the general liabilities and both other genes and environmental factors throughout development affect the likelihood of developing specific mental disorders.
\end{abstract}




\section{Introduction}

Comorbidity, or the tendency for disorders to co-occur at greater than chance rates (Clark, Watson, \& Reynolds, 1995), is high among psychiatric disorders, with estimates that nearly $60 \%$ of individuals with a lifetime DSM-IV psychiatric disorder have diagnoses of more than one disorder (Kessler, Berglund, Demler, Jin, \& Walters, 2005). Drug and alcohol use disorders are frequently comorbid with each other, and rates of substance use disorders (SUDs) are nearly three times as common among individuals with psychiatric disorders compared to individuals with no psychiatric disorder (Regier et al., 1990). Estimates from the National Comorbidity Survey-Replication (NCS-R) study indicate that SUDs are comorbid with antisocial disorders, mood disorders, and anxiety disorders. The likelihood of having a SUD was increased by six times among individuals with Conduct Disorder (CD; Nock, Kazdin, Hiripi, \& Kessler, 2006), and last 12-month diagnoses of SUDs were about six to seven times more common among individuals with Antisocial Personality Disorders (ASPD; Lenzenweger, Lane, Loranger, \& Kessler, 2007). Twenty-four percent of individuals with lifetime major depressive disorder (MDD) had a lifetime SUD diagnosis (Kessler et al., 2003), compared to lifetime estimates of $14.6 \%$ for SUDs in the general population (Kessler et al., 2005). The likelihood of having a SUD was 2.2 to 4.8 times greater among individuals with panic disorders (PD) and/or agoraphobia (Ago; Kessler et al., 2006), and subsequent SUDs were about twice as likely for individuals with Generalized Anxiety Disorder (GAD; Ruscio et al., 2007).

A great deal is known about the etiology of SUDs, including the typical developmental progression from behavioral and neurobiological predispositions to the emergence of SUDs during adolescence and early adulthood and the importance of both genetic and environmental influences on risk for SUDs. Considerably less is known about the origins of comorbidity with 
SUDs. This chapter provides a comprehensive review of the literature and describes an integrative model (Figure 1) to explain comorbidity among SUDs and other common mental disorders. The model is based on three central principles: (1) risk for psychopathology is multifactorial, reflecting cumulative effects of gene-environment interplay that begins in childhood and early adolescence, (2) covariance among common mental disorders is captured by two broad hierarchically organized dimensions characterized by externalizing and internalizing tendencies, and (3) the organization of this hierarchical system derives from genetically influenced biological dispositions to negative emotionality and at a lower level of the hierarchy to behavioral disinhibition, negative thought processes, and physiological hyperarousal. Our main thesis is that comorbidity can largely be explained by genetic liabilities for biological processes that give rise to these externalizing and internalizing dimensions, each of which is composed of related personality traits, cognitive processes, behavioral tendencies, and symptoms of psychopathology. In the sections that follow, we review empirical and theoretical support for this model from a developmental perspective and then describe how the model explains the comorbidity of SUDs with other psychiatric disorders. We begin by reviewing research on the underlying covariance structure of psychopathology, which forms the basis for the hierarchical common liabilities model.

\section{Common Genetic Liabilities}

The high comorbidity among psychiatric disorders suggests that psychopathology is encompassed by a smaller number of higher order constructs. Multivariate twin studies have modeled the covariance of depression, anxiety, substance use, and antisocial disorders to identify the latent structure underlying comorbidity. In these studies, the amount of genetic influence shared among different disorders is calculated by comparing monozygotic and dizygotic twin 
pairs on the degree of association between a phenotype (e.g., alcohol dependence) in one twin and a different phenotype (e.g., ASPD) in the co-twin. Shared genetic influences can be inferred when monozygotic twins have greater cross-phenotype similarity than dizygotic twins.

A meta-analysis of these multivariate studies (Krueger \& Markon, 2006) revealed a bestfitting model with two correlated superordinate factors underlying two broad spectra of disorders: (a) an externalizing (EXT) spectrum/factor that encompasses antisocial deviance (i.e., $\mathrm{CD}$ and ASPD) and substance abuse/dependence and is described as the propensity to express distress outward, and (b) an internalizing (INT) spectrum/factor that encompasses depressive (MDD and dysthymia) and anxiety disorders (GAD, phobias, PD) and is described as a propensity to express distress inward. In the best-fitting model, this INT factor was further subdivided into two highly correlated but distinct subfactors. One INT factor, which we have labeled anhedonia/misery (INT-AM), underlies the covariance of MDD, persistent depressive disorder (formerly dysthymic disorder), and GAD; and the second INT factor, which we have labeled fear/arousal (INT-FA), underlies agoraphobia, social anxiety disorder, specific phobia, and panic disorder. ${ }^{1}$ PD had a modest loading on the INT-AM factor as well, and given that other large multivariate twin studies (e.g., Kendler, Prescott, Myers, \& Neale, 2003) find that PD loads more strongly onto a factor with MDD and GAD, PD is depicted with loadings on both INT subfactors in our common liabilities model.

Twin and adoption studies support the substantial role of genes in the etiology of mental disorders. In childhood and early adolescence, genes contribute to individual differences in traits like aggression, inattention, and fearfulness (Bartels et al., 2007; Hirata, Zai, Nowrouzi, Beitchman, \& Kennedy; 2013; Trzaskowski, Zavos, Haworth, Plomin, \& Eley, 2012; 
Zai, Ehtesham, Choi, Nowrouzi, de Luca, Stankovich, et al., 2012), which are predictive of psychopathology later in adolescence and adulthood (e.g., Ormel et al., 2005; Pardini, Lochman, $\&$ Wells, 2004). Genetic factors contribute to disruptive behavior disorders, anxiety disorders, and depressive disorders in youth (Ehringer, Rhee, Young, Corley, \& Hewitt, 2006), and by adulthood, SUDs, antisocial behavior disorders, depressive disorders, and anxiety disorders are at least moderately heritable (Fu et al., 2002; Goldman, Oroszi, \& Ducci, 2005; Hettema, Prescott, Myers, Neale, \& Kendler, 2005; Sullivan, Neale, \& Kendler, 2000; Tully, Iacono, McGue, 2010). The hierarchical INT/EXT structure suggests that disorders that load onto the same factor share common core processes, and research suggests that these shared processes are likely genetically influenced. Kendler et al.'s (2003) study showed that the distinction between the INT and EXT factors was largely genetic rather than environmental in nature and that the two INT subfactors had distinct, although positively correlated, genetic loadings (Kendler, Prescott, Myers, \& Neale, 2003).

Disorders are most highly comorbid with other disorders with loadings on the same factor (Kessler et al., 2005). However, disorders that load onto different factors are also comorbid, albeit to a lesser extent. This cross-factor comorbidity reflects the fact that the INT and EXT factors are moderately correlated $(r=.50 ;$ Krueger \& Markon, 2006) and suggests shared etiology of disorders across factors. In our common liabilities model, comorbidity of INT and EXT disorders is largely explained by a general liability that influences risk for INT and EXT disorders. The higher comorbidity of disorders loading on the same factor is explained by additional genetic liabilities shared only among disorders of the EXT factor, the INT-AM subfactor, or the INT-FA subfactor. Environmental factors are also proposed to contribute to the etiology of mental disorders, and some environmental factors (e.g., high levels of stress) increase 
risk for various mental disorders and thus contribute to comorbidity. In addition, unique genetic and environmental risks specific to each disorder account for multifinality (Cicchetti \& Rogosch, 1996). In other words, they explain why individuals with the same general liability do not all experience the same outcomes. We begin our discussion of common genetic liabilities with the highest order liability that accounts for comorbidity across the INT and EXT factors.

\subsection{Negative Emotionality Liability}

Although best-fitting models from multivariate analyses of covariance identify two higher order latent factors, the cross-factor comorbidity and correlation between the two factors suggest the possibility of a higher order liability that influences disorders in both the INT and EXT factors. We posit that comorbidity between SUDs and both externalizing and internalizing psychopathology is due in part to a general, genetically influenced liability, which we have labeled negative emotionality (NE). This general liability is expressed as a spectrum of neurobiological processes, personality traits, and behavioral tendencies common to both INT and EXT disorders, such as proneness to experiencing negative emotions like sadness and anger, propensities toward inadequate emotion regulation abilities, and maladaptive responses to negative emotions and stress.

Support for NE as a general liability is derived from findings of genetic influences on variables related to the NE construct and from studies of NE-related personality traits underlying both INT and EXT disorders. For example, neuroticism is a personality trait characterized by emotional instability, vulnerability to stress, and proneness to anxiety (Eysenck, Eysenck, \& Barrett, 1985). Neuroticism is heritable (e.g., Birley et al., 2006) and has been associated with depression and anxiety (Gershuny \& Sher, 1998; Hettema, Neale, Myers, Prescott, \& Kendler, 2006; Kendler, Gardner, \& Prescott, 2002; 2006; Kendler, Gatz, Gardner, \& Pedersen, 2006; 
Klein, Kotov, \& Bufferd, 2011), antisocial behavior (Derefinko \& Lynam, 2006; Hicks \& Patrick, 2006; Taylor, Reeves, James, \& Bobadilla, 2006), and SUDs (Agrawal, Jacobson, Prescott, \& Kendler, 2004; Elkins, King, McGue, \& Iacono, 2006; Jackson \& Sher, 2003; Hur, 2009; James \& Taylor, 2007; Miller, Vogt, Mozley, Kaloupek, \& Keane, 2006). It has also been found to account for a significant proportion of the comorbidity between INT and EXT disorders (Khan, Jacobson, Gardner, Prescott, \& Kendler, 2005). In addition, Tellegen (1982) proposed a similar construct, also labeled negative emotionality, which is defined as a tendency to experience negative emotions and to become behaviorally dysregulated under stress. Negative emotionality prospectively predicts alcohol and marijuana dependence, CD, ASPD, depressive disorders, and anxiety disorders (Krueger, 1999a; Slutske et al., 2002; Tellegen, 1982).

Research on endophenotypes provides further support for shared NE-related genetic origins of INT and EXT disorders. Endophenotypes are attributes that are a product of genotypes that predispose to a disorder and are presumed to be more proximal to the genetic influences than clinical diagnoses themselves (Gottesman \& Gould, 2003; Iacono \& Malone, 2011). Disorders associated with the same endophenotypes likely share some of the same genetic influences (Yoon, Iacono, Malone, \& McGue, 2006). Accurate identification of endophenotypes ultimately requires research at the molecular level, but indices of biological processes (e.g., psychophysiology measures, levels of hormones and neurotransmitters) that are correlated with clinically relevant phenotypes and genetically influenced are plausible endophenotypes. Many neurobiological systems associated with $\mathrm{NE}$, in particular anger and responses to stress are common to both INT and EXT disorders. Corticotropin-releasing factor (CRF), the hypothalamic-pituitary-adrenal (HPA) axis, and noradrenergic pathways are involved in the body's stress response system and have been implicated in the pathophysiology of anxiety, 
mood, and addictive disorders (for review see Brady \& Sinha, 2005). Anger is largely regulated by dopaminergic and glutamate systems in the nucleus accumbens and prefrontal cortex, and neuroimaging and psychopharmacological treatment studies suggest that these systems also play a role in the neurobiology of depressive, anxiety, behavioral, and SUDs (for reviews see Koob et al., 2004; Lara \& Akiskal, 2006). Moreover, serotonin, dopamine, and CRF have been implicated in the etiology of substance-induced depression and anxiety (e.g., Markou, Kosten, \& Koob, 1998; Rounsaville, 2004; Zoltgn et al., 1995), thus providing more evidence for common endophenotypes for INT disorders and SUDs. The genetic basis of these neurobiological substrates and systems is supported by association studies of candidate genes involved in the stress response, particularly functional polymorphisms related to monoaminergic neurotransmission (e.g., in the loci encoding the serotonin transporter, tyrosine hydroxylase, catechol-o-methyltransferase, glucocorticoid receptor; for review see Levinson, 2006), and by research on phenotypic outcomes resulting from modifications of serotonin-related genes in rodents (for review see Holmes, 2008). These studies support the role of stress response polymorphisms in the neurobiology of neuroticism (Levinson, 2006), depression (Brouwer et al., 2006; Joensuu, et al., 2010; Levinson, 2006; Sarosi et al., 2008), and alcohol-related disorders (Clarke et al., 2008; Florez et al., 2008; Merenäkk, et al., 2011).

Understanding how NE liability contributes to high co-occurrence among disorders requires a developmental perspective. Trait negative emotionality is relatively stable from infancy through adulthood (Lonigan, Phillips, \& Hooe, 2003; Pedlow, Sanson, Prior, \& Oberklaid, 1993; Roberts \& DelVecchio, 2000; Rothbart, Ahadi, \& Evans, 2000), this stability is genetically mediated (e.g., Spengler, Gottschling, Spinath, 2012), and associations between NErelated constructs and psychopathology begin early in development. Dispositional measures of 
negative emotions, such as tendencies toward sadness, anger, irritability, and frustration, have been associated with internalizing and externalizing problems in young children (Eisenberg et al., 2001), preadolescents (Anthony \& Lonigan, 2002; Oldehinkel, Hartman, Winter, Veenstra, \& Johan, 2004), and adolescents (Silk, Steinberg, \& Morris, 2003). Measures of negative emotions early in childhood prospectively predict higher levels of psychopathology in late adolescence (Block, Gjerde, \& Block, 1991) and young adulthood (Caspi, Moffitt, Newman, \& Silva, 1996), and negative emotionality in late adolescence predicts subsequent development of major depression in adulthood (Wilson, DiRago, \& Iacono, 2013). In one study, examiners rated children's behavior at age 3 in an unselected Dunedin birth cohort sample. Factor and cluster analyses of these ratings revealed five behaviorally and emotionally distinct groups of children that differed in psychiatric diagnoses at age 21. Behaviorally inhibited children were most likely to grow up to have depression diagnoses, and behaviorally undercontrolled children were most likely to have diagnoses of alcohol dependence and ASPD. Both of these groups were characterized by high negative emotions, including fear and stranger distress for the inhibited group and irritability and emotionally liability for the undercontrolled group. Importantly, the three groups with low levels of psychiatric problems at age 21 did not have high levels of negative emotions, including a reserved group of children who were behaviorally comparable to the inhibited group but were not described as having fear and distress (Caspi et al., 1996). These findings highlight the role of NE in early developmental pathways leading to psychopathology and also suggest a mediating role of inadequate strategies for regulating and processing negative emotions.

The common liabilities model proposes that the general NE liability influences risk for INT and EXT disorders both directly by predisposing individuals to experience and express 
negative emotions and indirectly through interactions with genes for lower order genetic liabilities specific to the INT and EXT factors, in particular liabilities related to the regulation of behavior, emotion, and thoughts. Regulation difficulties for individuals with EXT disorders lead them to express the NE liability as dysregulated external behaviors (e.g., aggression toward others, illicit substance use), whereas regulation difficulties for individuals with INT disorders lead them to experience the NE liability as internal dysregulation (e.g., rumination, excessive attention to negative information, persistent distress). In this way, the NE factor increases the likelihood that INT or EXT factor-specific genes will be expressed as INT or EXT disorders, thus contributing to the comorbidity of disorders falling into the INT or EXT spectra.

\subsection{Regulation Liabilities}

In the common liabilities model, the genetic liability for NE-the propensity to experience negative emotions_-typically interacts with genetic liabilities underlying three types of emotion regulation difficulties to predict psychopathology. More specifically, the shared NE liability interacts with a liability to behavioral disinhibition (BD), which predisposes individuals to have difficulty regulating their behavioral responses to negative emotions and increases risk for externalizing disorders; and liabilities to negative thinking (NT) and physiological hyperarousal $(\mathrm{PH})$, which predispose individuals to have difficulty internally regulating and processing negative emotions and increases risk for internalizing disorders. Theory and research from the developmental literature support this idea that internalizing and externalizing symptoms stem from a combination of propensities to experience negative emotions and propensities toward inadequate control of these emotions. Various models of child temperament propose both reactive traits (e.g., automatic behaviors and unregulated fear) and effortful or active traits (e.g., self-regulation abilities and purposeful attentional focus) as components of developmental paths 
leading to psychopathology (Derryberry \& Rothbart, 1988; 1997; Kochanska, Barry, Jimenez, Hollatz, \& Woodard, 2009; Lonigan et al., 2004; Muris \& Ollendick, 2005; Rothbart, 1989; Rothbart, Ahadi, \& Hershey, 1994; Rothbart, Posner, \& Hershey, 1995). A study involving a Dutch population-based sample of adolescents found that predispositions toward low effortful control (i.e., tendencies to voluntarily inhibit a dominant response in order to perform a subdominant but more adaptive response) magnified the effect of fearfulness on internalizing problems and the effect of frustration on externalizing problems in adolescents (Oldehinkel, Hartman, Ferdinand, Verhulst, \& Ormel, 2007), and effortful control and negative affect were associated with familial loadings for both internalizing and externalizing psychopathology (Ormel et al., 2005). In the next two sections, we describe the regulation liabilities in greater detail from a developmental perspective.

\subsubsection{Behavioral Disinhibition Liability for Externalizing Disorders}

The EXT latent factor has been associated with low constraint in Tellegen's (1982) personality model (Krueger, McGue, \& Iacono, 2001), indicating that individuals high in EXT tend to be impulsive and thrill-seeking and have low adherence to traditional moral values. The common liabilities model proposes that the high comorbidity among externalizing disorders is due to a common genetic liability for traits, behaviors, disorders, and endophenotypes that reflect a propensity toward behavioral disinhibition (BD), such as inattention, aggressiveness, impulsivity, and low persistence (for a complete review see Iacono, Malone, \& McGue, 2008).

Twin and adoption studies support shared genetic influences underlying the traits and disorders in the EXT spectrum. Multivariate studies indicate shared genetic influences underlying dependence on various licit substances (Agrawal et al., 2007; Lynskey et al., 2007; Swan, Carmelli, \& Cardon, 1996; True, Xian et al., 1999), common genetic influences on 
different drugs in the illicit substance classes (Agrawal, Neale, Prescott, \& Kendler, 2004a;

Karkowski, Prescott, \& Kendler, 2000; Kendler, Aggen, Tambs, \& Reichborn-Kjennerud, 2006;

Kendler, Jacobson, Prescott, \& Neale, 2003; Tsuang et al., 1998), and either shared genetic influences on dependence across licit and illicit substances (Agrawal \& Lynskey, 2006; Hopfer, Crowley, \& Hewitt, 2003; True, Heath et al., 1999) or highly correlated genetic influences on licit and illicit factors ( $r=.82$; Kendler, Myers, \& Prescott, 2007). Other studies support significant genetic covariation between SUDs and disruptive behavior disorders in childhood (Burt, Krueger, McGue, \& Iacono, 2001; Button et al., 2006; Button et al., 2007; Dick, Viken, Kaprio, Pulkkinen, \& Rose, 2005; Nadder, Rutter, Silberg, Maes, \& Eaves, 2002; Silberg et al., 1996) and between SUDs and adult antisocial behavior disorders (Hicks, Foster, Iacono, \& McGue, 2013; Hicks, Krueger, Iacono, McGue, \& Patrick, 2004). Moreover, latent EXT factors comprised of SUDs and antisocial disorders are highly heritable (Hicks et al., 2007; Hicks, Schalet, Malone, Iacono, \& McGue, 2011; Kendler, Prescott et al., 2003). Finally, research supports shared genetic risks underlying EXT disorders and other behavioral disinhibition attributes, such as the personality traits of novelty seeking (Khan et al., 2005) and behavioral undercontrol (Krueger et al., 2001; Slutske et al., 2002), and early adolescent problem behaviors like substance experimentation and use, sexual intercourse, and police contact (Keyes, Iacono, \& McGue, 2007; McGue, Iacono, \& Krueger, 2006; Young, Stallings, Corley, Krauter, \& Hewitt, 2000).

Research on biologically based endophenotypes provides further support for a common EXT genetic liability. Reduced amplitude of the P300 wave, a nonspecific index of brain activity, is a well-studied endophenotype that has been associated with childhood disruptive behavior disorders and antisocial personality disorder (Iacono, Carlson, Malone, \& McGue, 
2002), substance misuse and SUDs (Carlson, McLarnon, \& Iacono, 2007; Iacono et al., 2002; Yoon et al., 2006), and the externalizing latent trait (Patrick, 2006). Although the biological systems underlying individual differences in the P300 wave (Burwell, Malone, Bernat, \& Iacono, 2014) are not well understood, individual differences in P300 amplitude predict subsequent development of EXT disorders (Iacono et al., 2002; Perlman, Markin, \& Iacono, 2013), are heritable (van Beijsterveldt \& van Baal 2002; Perlman, Johnson, \& Iacono, 2009; van Beijsterveldt \& van Baal, 2002; Yoon et al., 2006), and the association between attenuated P300 amplitude and externalizing disorders is genetically mediated (Hicks et al., 2007a).

The midbrain dopamine reward system is a neurobiological mechanism involved in addiction to virtually all drugs of abuse (Kosten, George, \& Kleber, 2005; Nestler, 2005) that has been proposed to underlie aggressive behavior as well (Patrick, 2006), which provides further support for genetic liability shared among SUDs and antisocial disorders. Consistent with this, Gray's model of motivational systems proposes two neurologically based personality systems: (a) the behavioral activation system (BAS), which is exhibited as sensitivity to rewards and motivation to engage in goal-directed efforts to experience positive feelings; and (b) the behavioral inhibition system (BIS), which refers to sensitivity to punishments and proneness to inhibit behavior that may lead to negative or painful outcomes (Gray, 1972; 1975; 1981). EXT disorders likely reflect increased BAS activation, in the form of midbrain reward system, and decreased BIS activation (Iacono et al., 2008), which is likely related to diminished prefrontal cortex functioning and difficulty regulating behavior and inhibiting inappropriate responses (Bechara, 2005; Miller \& Cohen, 2001). BIS and BAS impairment across EXT disorders underlies high comorbidity among EXT disorders, whereass cross-disorder differences in BIS/BAS impairment is related to different outcomes among individuals with the BD liability. 
Individuals with SUDs tend to have more BAS problems, individuals with antisocial disorders tend to have more BIS problems, and individuals with comorbid SUDs and antisocial disorders tend to have problems with both systems.

Consideration of developmental research is again key to understanding how this genetic liability contributes to comorbidity. The BD liability is expressed as different phenotypes over the course of development with the same early temperament traits predicting various subsequent EXT disorders. Behavioral disinhibition traits, such as lack of inhibitory control, novelty seeking, and low harm avoidance, when expressed during early childhood predict subsequent substance use and misuse during adolescence (Caspi, Henry, McGee, Moffitt, \& Silva, 1995; Caspi et al., 1996; Masse \& Tremblay, 1997; Wong et al., 2006), and the same traits assessed during late childhood, adolescence, and young adulthood predict tobacco, alcohol, and illicit drug symptoms and disorders in later in adulthood (Chassin, Fora, \& King, 2004; Cloninger, Sigvardsson, \& Bohman, 1988; Elkins et al., 2006; Grekin, Sher, \& Wood, 2006; Krueger, 1999a; Sher, Bartholow, \& Wood, 2000). These traits also manifest as disruptive behavior disorders (e.g., Oppositional Defiant Disorder, CD) during childhood (Young, et al., 2009), which are predictive of later SUDs (Kim-Cohen et al., 2003; Weinberg, Rahdert, Colliver, \& Glantz, 1998), and as high-risk behaviors during early adolescence, such as antisocial behavior, experimentation with alcohol, precocious sexual activity, and academic difficulty, which in turn predict later SUDs and ASPD (Grant \& Dawson, 1997; McGue \& Iacono, 2005).

These early universal EXT traits become more differentiated across development. Caspi et al. (1995) found one latent factor for lack of control at ages 3 and 5 that became 2 distinct factors (an impulsive/undercontrolled factor and a fleeting attention/lack of persistence factor) by ages 7 and 9 (Caspi et al., 1995). Likewise, a longitudinal study investigating change in the 
underlying structure of the EXT factor from age 17 to 24 found a decrease in the amount of overlapping variance among externalizing disorders with age (Hicks et al., 2007), reflecting decreased genetic influence on the covariation among disorders (Vrieze, Hicks, Iacono, \& McGue, 2012). In addition, greater differentiation with age may be due to varied environmental risk exposure and age-related expression of genes that are specific to certain externalizing attributes (Agrawal, Neale, Prescott, \& Kendler, 2004b; Grant et al., 2006; Hicks et al., 2004; Kendler, Prescott et al., 2003; Krueger et al., 2002; McGue et al., 2006; Young et al., 2000). These disorder-specific effects account for relative differences in the extent to which the shared liabilities contribute to the development of specific disorders and explain why only some and not other externalizing disorders appear in a given individual with the BD liability. For example, individuals with extreme antisocial tendencies are likely to be high in BD and relatively low in NE (Patrick, 2006).

\subsubsection{Liability for Internalizing Disorders}

Genetic risk factors associated with NE contribute substantially to the genetic overlap among internalizing disorders (Bienvenu, Hettema, Neale, Prescott, \& Kendler, 2007; Fanous, Gardner, Prescott, Cancro, \& Kendler, 2002; Fanous, Neale, Aggen, \& Kendler, 2007; Gillespie \& Martin, 2006; Hansell, et al., 2012; Hettema, Neale et al., 2006; Hettema, Prescott, \& Kendler, 2004; Kendler \& Gardner, 2011; Levinson, 2006). Therefore, we do not propose a specific liability for the INT factor but rather propose that the NE liability has a strong genetic influence on the internalizing factor and underlies all depressive and anxiety disorders. Consistent with the multivariate twin studies, we posit two subfactor-specific genetic liabilities. A liability to physiological hyperarousal $(\mathrm{PH})$ underlies the disorders in the fear/arousal subfactor (i.e., agoraphobia, social phobia, specific phobia, and PD) and is expressed as 
psychophysiological/somatic signs, fear, heightened attention to threats, and behavioral inhibition. A liability to negative thought processes (NT), including worry, rumination, and negatively biased attention and interpretation, underlies disorders in the anhdeonia/misery subfactor (i.e., MDD, persistent depressive disorder, GAD, and PD) and is expressed as habitual negative attributions and expectations and low positive affect.

This structure for a general NE liability and subfactor-specific PH and NT liabilities is similar to the tripartite model (Clark \& Watson, 1991) and the integrative hierarchical model (Mineka, Watson, \& Clark, 1998). The tripartite model proposes a general distress/negative affectivity dimension that is common to both depression and anxiety disorders as well as an anhedonia (low positive affect) factor specific to depression and a physiological hyperarousal factor specific to anxiety. Our integrative hierarchical model combines elements of the tripartite model and Barlow's hierarchical organization of the anxiety disorders (Barlow, 1991; Zinbarg \& Barlow, 1996) and posits that each anxiety and depressive disorder contains both a common component and a unique component. These models propose a general negative affectivity factor that accounts for a large proportion of variance in MDD and GAD and a much smaller proportion of the variance in most other anxiety disorders (e.g., social phobia, specific phobia) and that negative affectivity and low positive affectivity characterize many noninternalizing disorders. Watson (2005) further proposed a quantitative hierarchical model in which a general emotion disorders category can be subdivided into the bipolar disorders (bipolar I, bipolar II, cyclothymia), the distress disorders (MDD, dysthymic disorder, GAD, and PTSD), and the fear disorders (panic disorder, agoraphobia, social phobia, and specific phobia; Watson, 2005).

Analogous to the developmental progression of the BD liability, behavioral inhibition, specifically when it is characterized by poor autonomic regulation (Marshall \& Stevenson-Hinde, 
1998), typically appears during early childhood in individuals who will later develop anxiety (Hirshfeld-Becker et al., 2007; McDermott, et al., 2009), and anxiety may be an earlier expression of the common NE liability than depression. Anxiety is more likely than depression to onset during childhood, depression in child and adolescent samples is most often comorbid with anxiety (Anderson, Williams, McGee, \& Silva, 1987; Angold, Costello, \& Erkanli, 1999; Fleming, Offord, \& Boyle, 1989), and the onset of anxiety tends to precede the onset of depression (Hettema, Kuhn et al., 2006; Kessler et al., 2005; Woodward \& Fergusson, 2001). Twin studies of children and adolescents support significant genetic covariation between anxiety and subsequent depression that cannot be explained by genetic influences associated with earlier depression (Eaves et al., 2003; Rice et al., 2004), suggesting shared genetic etiology of childhood anxiety and later depression. Anxiety and depression do not always co-occur and anxiety does not always precede depression, but these findings support a common liability underlying the two separate INT subfactors.

Research on associations between temperament/personality traits and depressive and anxiety disorders supports the PH and NT liabilities. Many concurrent and a few prospective studies of children and adolescents have consistently found associations between high negative affect/neuroticism and both depression and anxiety, low positive affect/surgency and depression, and high physiological arousal and anxiety (e.g., Caspi et al., 1996; Chorpita \& Daleiden, 2002; Compas, Conner-Smith, \& Jaser, 2004; Lonigan, Carey, \& Finch, 1994). Studies involving adult samples have similar findings. Internalizing factors defined by both depression and anxiety symptoms tend to have smaller correlations with positive emotionality than with negative emotionality (Krueger et al., 2001). Krueger (1999b) found a significant negative association between depressive disorders and the well-being dimension of Tellegen's Multidimensional 
Personality Questionnaire (which is described as cheerfulness, optimism, and proneness to enjoyment) and no association between well-being and anxiety disorders (Krueger, 1999a). In a similar way, constraint, a personality factor defined as a propensity for cautious and restrained behavior and endorsement of traditional values, does not typically correlate with the general INT factor (Krueger et al., 2001), and high constraint is characteristic of individuals with anxiety disorders but not depressive disorders (Krueger, 1999a). Consistent with the specificity of constraint to the PH liability, Gladstone et al. (2006) found that social anxiety mediated the relationship between childhood inhibition and later depression (Gladstone, Parker, Gladstone, \& Parker, 2006).

2.2.2.1 Physiological Hyperarousal Liability. Some anxiety is normative, particularly in infancy and toddlerhood in response to separation from parents. This fear typically diminishes dramatically during early childhood (Muris, Meesters, Merckelbach, Sermon, \& Zwakhalen, 1998), an age when fear-based anxiety disorders, such as separation anxiety disorder, social phobia, and specific phobias, are likely to onset (Kessler et al., 2005). Fear in these young children has significant genetic overlap with shyness/inhibition (62\%) and negative mood (53\%; Eley et al., 2003), suggesting developmental continuity with later internalizing disorders that share these traits, particularly disorders in the FA subfactor. These disorders are characterized by behavioral constraint (Krueger, 1999a) and intense physiological hyperarousal (PH), such as heart racing, sweating, and shortness of breath particularly in response to stressors (Cuthbert et al., 2003; Hofmann, Moscovitch, \& Kim, 2006; Martin-Soelch, Stocklin, Dammann, Opwis, \& Seifritz, 2006).

Turning to evidence of potential endophenotypes, research on psychophysiological characteristics of anxious and depressed individuals supports the distinction of the PH and NT 
liabilities within internalizing psychopathology. Anxiety disorders loading on the FA factor are characterized by poor parasympathetic flexibility (Licht, de Geus, van Dyck, \& Penninx, 2009; Sharma, Balhara, Sagar, Deepak, \& Mehta, 2011) and exaggerated sympathetic arousal to affectively arousing stimuli, especially fear stimuli (Cuthbert et al., 2003; Larson, Nitschke, \& Davidson, 2007). Cuthbert et al. (2003) found that individuals with PD were less physiologically responsive to the affective stimuli than individuals with specific phobias and social anxiety, a finding that is consistent with PD's relatively smaller genetic loading on the FA factor (Kendler, Prescott et al., 2003). Moreover, depressed individuals without anxiety disorders and anxious individuals with worry or anhedonic symptoms but not arousal symptoms do not show exaggerated physiological responses to these stimuli (Larson et al., 2007), and researchers have found blunted physiological responses to pleasant stimuli among individuals with depression (Forbes, Miller, Cohn, Fox, \& Kovacs, 2005; Larson et al., 2007). A comprehensive review of this literature supports these conclusions (Vaidyanathan, Patrick, \& Cuthbert, 2009) and links the differentiation of INT disorders to distinct underlying brain systems. Few studies have investigated the heritability of these psychophysiological indices. The extant literature supports modest genetic influences on conditioned eyeblink responses (Merrill, Steinmetz, Viken, \& Rose, 1999) and on absolute startle reflex but not emotion-modulated startle reflex (Anokhin, Golosheykin, \& Heath, 2007; see also Carlson, Katsanis, Iacono, \& McGue, 1997). Research on the heritability of these psychophysiological indices is needed to establish their potential as endophenotypes for FA-INT disorders.

The amygdala is the primary brain structure for processing fear, and it has been linked to behavioral inhibition (Haas, Canli, Haas, \& Canli, 2008; Kensinger \& Corkin, 2004; Morgan \& Morgan, 2006), suggesting neural substrates implicated in the functioning of the amygdala are 
also potential endophenotypes for FA-INT disorders and their precursors. Pharmacological studies indicate that blockage of receptors in the amygdala (e.g., $N$-methyl- $D$-aspartate, NMDA, receptors) inhibits fear responses and consolidation of fear memories, and NMDA antagonists successfully treat various anxiety disorders (Garakani, Mathew, \& Charney, 2006). Impairment in amygdala functioning is also implicated in nonfear disorders (e.g., MDD), but genes associated with functioning of the amygdala receptors and neurotransmitters that bind to these receptors likely contribute considerably to the $\mathrm{PH}$ liability. Research showing associations between anxiety disorders and measures of heart rate variability and respiratory sinus arrhythmia in response to emotion-laden stimuli (e.g. Licht et al., 2009; Porges, 2011) suggest the physiological substrates underlying parasympathetic functioning may also be key endophenotypes.

2.2.2.2 Negative Thought Processes Liability. Twin studies have demonstrated substantial genetic covariance between MDD and GAD, and a significant proportion of that genetic overlap is due to the common genetic liability for NE (Hettema, Neale et al., 2006; Kendler, Gardner, Gatz, \& Pedersen, 2007; Middeldorp, Cath, Van Dyck, \& Boomsma, 2005). Nevertheless, Hettema et al. (2006) found a significant genetic factor shared among MDD, GAD, and PD that was independent from the genetic influences of neuroticism, and Kendler et al. (2007) found that only about $25 \%$ of the genetic correlation between MDD and GAD was shared with neuroticism, leaving a considerable amount of shared genetic variation to be explained by other factors. We propose that the comorbidity among the disorders in the INT-AM subfactor are explained by a genetic predisposition for various interrelated negative thought (NT) processes that have empirical links to depression and anxiety, including attentional biases to threatening and sad stimuli, excessive contemplation of negative information, difficulty shifting attention away from 
negative information, and trouble suppressing pessimistic cognitions (e.g., Bradley, Mogg, White, Groom, \& de Bono, 1999; Everaert, Koster, \& Derakshan, 2012; Gotlib \& Joormann, 2010; Hirsch, Clark, \& Mathews, 2006; Mathews \& MacLeod, 2005; Mogg, Philippot, \& Bradley, 2004; Vanderhasselt, et al., 2012; Zetsche, D'Avanzato, \& Joormann, 2012). This predisposition underlies cognitive characteristics of these disorders, like worry, rumination, hopelessness, and negative attributions about the self and the future (e.g., Alloy et al., 2004; Nolen-Hoeksema, Wisco, \& Lyubomirsky, 2008; Papageorgiou, 2006), as well as anhedonia and low levels of positive affect which are also characteristics of these disorders (Krueger, 1999a; Watson, 2005). Individuals with an INT-AM disorder inherit both the NE liability and the NT liability and thus are prone to high levels of fear, anger, and sadness and to maladaptive cognitive processing and internal regulation of these negative emotions.

This cognitively based NT liability is consistent with the many cognitive theories of depression and anxiety, such as Beck's cognitive distortion model (Beck, 1967; 1976), the learned helplessness and hopelessness models (Abramson, Metalsky, \& Alloy, 1989; Abramson, Seligman, \& Teasdale, 1978; Seligman, 1974), Eysenck’s hypervigilance theory of anxiety (Eysenck, 1992; 1997), and Beck's information processing model of anxiety (Beck \& Clark, 1997). Furthermore, the combination of NE and NT liabilities is supported by transdiagnostic emotion regulation models that propose maladaptive cognitive regulation of negative emotions contribute to depression and anxiety (Aldao \& Nolen-Hoeksema, 2010; Gross \& Thompson, 2007; Hofmann, Sawyer, Fang, \& Asnaani, 2012) and findings that cognitive processes, such as attentional biases toward threatening stimuli, moderate associations between behavioral inhibition and internalizing problems (e.g., Fox \& Pine, 2012; Pérez-Edgar et al., 2011). 
Although few studies have investigated the heritability of the many cognitive constructs associated with depression and anxiety, the few existing studies generally support moderate genetic influences on these constructs. Attributional style, a cognitive pattern characterized by internal, global, and stable attributions for negative events, was found to be moderately heritable (35\%; Lau, Rijsdijk, \& Eley, 2006) in a sample of adolescents, and anxiety sensitivity, which refers to beliefs about the harmful consequences of anxiety, was also moderately heritable in samples of adolescents (60\%; Eley \& Brown, 2004) and adults (45\%; Stein, Jang, \& Livesley, 1999). Eley and colleagues studied genetic influences on various simple cognitive variables in 8year-old children. They found significant genetic influences on anxiety sensitivity (37\%; Eley, Gregory, Clark, \& Ehlers, 2007) but negligible genetic influences and significant shared environmental on negative interpretations of interpersonal relationships (Gregory et al., 2007). Genetic influences on anxiety sensitivity were highly correlated with genetic influences on panic/somatic symptoms of anxiety in children (Eley et al., 2007), and genetic influences on a measure of children's interpretations of situations as either negative or neutral were significantly correlated ( $r=.65)$ with genetic influences on children's depressive symptoms (Eley et al., 2008).

Like the BD and PH liabilities, the NT liability should be conceptualized in a developmental context as behavioral tendencies, temperament traits, and physiological processes begin to emerge in childhood and predispose individuals to develop INT-AM disorders. Although the ability to internally regulate emotions emerges in the first year of life (e.g., selfsoothing), self-regulation abilities continue to develop rapidly through the critical preschool years and into childhood and adolescence (Cole, Michel, \& Teti, 1994; Gralinski \& Kopp, 1993; Kaler \& Kopp, 1990; Rothbart, Posner, \& Rosicky, 1994). Young children, who lack the cognitive abilities to develop stable expectancies and explanations for stress and negative 
emotions, express maladaptive internal regulation as behavioral restraint, shyness, and low attention regulation (Cicchetti \& Tucker, 1994; Eisenberg et al., 2001; Nolen-Hoeksema, Girgus, \& Seligman, 1992; Turner \& Cole, 1994). Improved cognitive abilities during late childhood and adolescence allow for the development of more stable and pathological cognitive styles, such as pessimistic beliefs about causes and consequences of stressful events and hopelessness about the future (Kaslow, Adamson, \& Collins, 2000; Nolen-Hoeksema et al., 1992). By early adolescence, rumination, poor ability to shift attention away from aversive or negative stimuli when desired, high self-criticism, dysfunctional interpretation schemas, hopelessness about the future, and negative views of self, world, and future are associated with higher levels of internalizing problems (Bachanas \& Kaslow, 2001; Murisa, Meesters, \& Blijlevens, 2007; Oldehinkel et al., 2004; Silk et al., 2003).

With respect to endophenotypes, studies linking depression and anxiety to genes related to serotonergic modulation of the stress response (e.g., serotonin transporter gene; Holmes, 2008; Koller et al., 2008) and genes linked to HPA axis regulation (e.g., glucocorticoid receptor gene; Brouwer et al., 2006; Papiol et al., 2007) suggest that biological markers of HPA axis and serotonergic system functioning may be promising INT-AM disorder endophenotypes. Complex interactions between genetic susceptibility to serotonergic and noradrenergic system dysfunction and stress-related changes in the HPA axis have been implicated in the etiology of depression (Firk, Markus, Firk, \& Markus, 2007; Porter et al., 2004), and psychopharmacological treatment studies support the role of reduced neurotransmission of serotonin and norepinephrine in the pathophysiology of GAD (Nutt, Argyropoulos, Hood, \& Potokar, 2006). Despite the extensive body of research linking corticotrophin-releasing factor and the HPA axis to depression (Hankin, Badanes, Abela, \& Watamura, 2010; Nemeroff \& Vale, 2005; Wardenaar, et al., 2011), almost 
no research has investigated the role of the HPA axis in the etiology of GAD separate from the INT-FA anxiety disorders. Although findings of associations between the HPA axis functioning and anxiety disorders in general have been mixed (Risbrough \& Stein, 2006), evidence from a study of HPA functioning in GAD patients showed significant changes in plasma cortisol following cognitive treatment (Tafet, Feder, Abulafia, \& Roffman, 2005).

\subsection{Molecular Genetics: Identifying Genes}

At present, the specific genes associated with the NE, BD, PH, and NT liabilities are unknown, and thus we limit our discussion of candidate genes to a few brief comments. Interpreting research on candidate genes for psychiatric disorders and personality traits is complicated because effects are likely due to multiple genes, each of which has small effects. Very large samples, replication across samples, and strong biologically informed a priori hypotheses are needed to place candidate gene findings on solid footings, and even then there is reason to be cautious regarding the likelihood that reported effects are not false-positive errors, especially when testing for gene x environment interactions (Duncan \& Keller, 2011). Nevertheless, promising leads are being developed, and findings from molecular genetic studies support common genetic liabilities. Studies support over-transmission of the risk variants of various genes in individuals with different psychiatric disorders. For example, the muscarinic acetylcholine receptor $\mathrm{M}_{2}$ gene $(C H R M 2)$ is involved in the stress response system among other functions (e.g., attention, learning, memory and cognition) and has been linked to alcohol and drug dependence (Wang et al., 2004), a general composite externalizing factor (Dick et al., 2008), and depression (Comings et al., 2002). In addition, findings regarding genes involved in SUDs (e.g., related to dopamine functioning) have also been implicated in BD traits like 
impulsivity and risk taking (Hiroi \& Agatsuma, 2005; Kreek, Nielsen, Butelman, \& LaForge, 2005) and the association between neuroticism and SUDs (Ellis et al., 2011).

\section{Environmental Mediation and Moderation of Genetic Liabilities}

Environmental factors are also important to the etiology of mental disorders and thus may contribute to comorbidity. In the common liabilities model, environmental risks are depicted as coalescing under a general factor that is influenced by the genetic liabilities and influences both INT and EXT psychopathology. By and large, environmental risks overlap extensively across disorders and EXT/INT factor groups. For example, low family support, conflict with peers, peer pressure, and broken relationships are associated with risk for substance use and depression in a sample of adolescents (e.g., Aseltine, Gore, \& Colten, 1998). Nevertheless, some environmental risk factors are likely to influence certain disorders to a greater degree than other disorders, and thus contribute to disorder specific effects, for example, peer pressure may be a stronger predictor of substance use and conflict with friends may be a stronger predictor of depression (Aseltine et al., 1998). Consistent with largely shared but some specific environmental effects, findings from a multivariate twin study suggest that factor-specific environmental risks do not distinguish INT disorders from EXT disorders, although some environmental influences are likely specific to smaller subsets of disorders, such as CD and ASPD and MDD, GAD, and alcohol dependence (Kendler, Prescott et al., 2003).

The influence of environmental risk mechanisms on comorbidity is due in part to the tendency for multiple environmental risks to co-occur. For example, exposure to interparental conflict in the home is related to conflict with peers and peer rejection (Hipwell, Murray, Ducournau, \& Stein, 2005; Kunz, 2001), and exposure to criminal and violent acts, deviant peers, and drug accessibility (all risk factors for both substance use and depression) tend to co- 
occur in the same neighborhoods (Curry et al., 2008; Stockdale et al., 2007; Valdez, Kaplan, \& Curtis, 2007). "Environmental" risk factors, such as family conflict and affiliation with deviant peers, have been found to be genetically influenced (McGue, Elkins, Walden, \& Iacono, 2005; Plomin \& Bergeman, 1991; Tarantino et al., 2014), and thus genetic factors may also contribute the co-occurrence of multiple environment risks.

Research supports the "cumulative risk hypothesis" that added exposures to multiple risks across different stages of development convey greater risk than single exposure or exposure in a single developmental period. This repeated exposure to environmental risks also amplifies gene expression through gene-environment (G-E) interplay (Rutter \& Silberg, 2002), which contributes to increased heritability of most mental disorders with age (Bergen et al., 2007). Gene-environment correlation is one mechanism of G-E interplay that contributes to comorbidity (Jaffee \& Price, 2007). Genetic and environmental risks are correlated because parents transmit risk to offspring both by passing on genes to their offspring and by shaping their offspring's environment (contributing to "passive" G-E correlations) and because genetically influenced behavior directly influences the environment (contributing to "active" G-E correlations). For example, genetic liability to BD increases risk for both EXT disorders and exposure to environmental factors like parental conflict and affiliation with defiant peers (Keyes et al., 2007), which are nonspecific environmental factors that potentiate risk for EXT and INT disorders. Environmental factors also interact with genetic factors to increase or decrease risk for disorders. For example, genetic influences on substance use and deviant behaviors are amplified in urban settings where environmental risks (e.g., easy access to drugs, exposure to violence, and perhaps less parental monitoring) are more common than in rural environments (Legrand, Keyes, McGue, Iacono, \& Krueger, 2007; Rose, Dick, Viken, \& Kaprio, 2001). As follows, 
environmental risks may also contribute to comorbidity by increasing the likelihood that common and disorder-specific genetic liabilities are expressed as mental disorders. Thus, genes and the environment influence each other and risk for disorders in a complex, reciprocal ways, and, importantly, because neither the genetic nor the environmental risk factors are disorderspecific, these G-E interplay mechanisms contribute to comorbidity of mental disorders.

\section{Explaining Co-occurrence of SUDs and Other Disorders}

Our common liabilities model explains comorbidity among mental disorders in general. In this section, we focus on how the model explains comorbidity with SUDs in particular and highlight some important assumptions of the model. The degree of influence of a given mechanism on the comorbidity of SUDs with another disorder varies from disorder to disorder. Likewise, the mechanism underlying the co-occurrence of two disorders in a given individual varies from person to person. Characteristics of the two disorders, such as age of onset and temporal order of emergence of the disorders, provide insight about the mechanisms underlying comorbidity.

\subsection{Behavioral Disinhibition Liability: Link between SUDs and Antisocial Disorders}

The model proposes that the BD genetic liability is the most likely factor underlying the comorbidity of SUDs with antisocial behavior disorders, and that when SUDs are comoribid with antisocial disorders the age of initiation of substance use is typically during early adolescence. As we have previously discussed, the typical progression of externalizing problems related to the BD liability is (a) impulsivity, inattention, and aggressiveness during early childhood; (b) disruptive behavior disorders during childhood; (c) antisocial behaviors, initiation of substance use, precocious sexual activity, affiliation with deviant peers, and parent-child conflict during 
early to mid-adolescence; and, finally (d) finally the emergence of alcohol and drug abuse/dependence and ASPD in adulthood (Iacono et al., 2008).

In a review of comorbidity of SUDs in samples of youth, Armstrong and Costello (2002) report that approximately $60 \%$ of youth with an SUD have a comorbid disorder, and early-onset SUDs are most often comorbid with CD and oppositional defiant disorder (Armstrong \& Costello, 2002). A longitudinal study of childhood internalizing and externalizing disorders and early adolescent substance use supports this idea. King, et al., (2004) found that disruptive behavior disorders (CD, ODD, and, to a lesser extent, ADHD) in male and female 11-year-olds were robust predictors of age 14 substance use behaviors (e.g., use of alcohol, cigarette, and cannabis one or more times per month and being drunk; King, Iacono, \& McGue, 2004). MDD and anxiety disorders were much less consistently predictive of substance use behaviors at age 14. Thus, through a developmental progression of expressed externalizing traits, behaviors, and environmental risks, the comorbidity of SUDs with CD and ASPD is most likely influenced through a general genetic liability to BD.

\subsection{General NE liability: Link between Alcohol Use Disorder and Anhedonia/Misery Disorder}

In the model, the NE liability has its greatest influence on INT disorders, particularly the INT-AM disorders, and the model proposes that NE also has a strong effect on alcohol use disorder (AUD) and contributes to the high comorbidity between alcoholism and depression. Several lines of research support this idea. First, although alcohol dependence has a stronger loading on the EXT factor than the INT factor, there is evidence from twin studies that nevertheless suggests some shared latent covariance between alcohol dependence and the INT factor (Kendler, Prescott et al., 2003; King et al., 2004; Krueger et al., 2001). Second, twin studies have demonstrated that genetic factors underlie the comorbidity of depression and 
alcohol dependence (Kendler, et al., 1993; Prescott, Aggen, \& Kendler, 2000). Third, although high negative emotionality has been associated with substance dependence in general (Krueger, 1999a), it appears to have an especially strong association with AUD. McGue and colleagues $(1997 ; 1999)$ found that alcohol dependence is particularly common among individuals who have high levels of both behavioral disinhibition and negative emotionality and that alcohol dependence is primarily associated with negative emotionality, while illicit drug use disorders are primarily associated with constraint (McGue, Slutske, \& Iacono, 1999; McGue, Slutske, Taylor, \& Iacono, 1997). Similarly, Elkins et al. (2004) found that adolescent offspring of parents with a history of alcohol dependence scored significantly higher on negative emotionality than adolescents with no parental history of alcohol dependence, and negative emotionality did not differ for offspring of parents with and without a drug abuse/dependence history (Elkins, McGue, Malone, \& Iacono, 2004). They found that this pattern characterized both offspring with an SUD and those who had not yet developed an SUD, which supports negative emotionality as an indicator of familial risk for alcoholism.

Fourth, research suggests that understanding how the NE liability mechanism contributes to the comorbidity of SUDs and internalizing disorders requires studying specific negative emotions (e.g., Lara, Pinto, Akiskal, \& Akiskal, 2006). Findings suggest that irritability and anger are associated with both alcohol use and depression but not with anxiety (Fava, et al., 2010; Hussong \& Chassin, 1994; Lara et al., 2006; Pardini et al., 2004; Tarter, Blacksona, Brighama, Mossa, \& Caprarab, 1995). These findings suggest that NE-related proneness toward irritability and anger may underlie the comorbidity of alcohol dependence and internalizing disorders within the INT-AM factor specifically. The proneness toward irritability and anger is likely influenced by disorder-specific genetic and environmental factors and perhaps 
by the environmental factors that Kendler et al. (2003) found were shared among MDD, GAD, and alcohol dependence. The factors underlying the comorbidity of alcohol dependence with INT-FA disorders would likely be different and perhaps involve specific effects that remain to be identified.

\subsection{Environmental Mechanisms}

Environmental factors likely contribute to the comorbidity of SUDs with both INT and EXT disorders through shared environmental risk factors, the tendency for multiple environmental risks to co-occur, and G-E interplay. We expect, though, that environmental risk factors are relatively more influential than genetic factors when the comorbid SUD has a late onset and the relative influence of environmental factors to genetic factors is greater for the comorbidity between SUDs and INT disorders than SUDs and EXT disorders. Because the BD liability is likely to be expressed as substance use relatively early in adulthood or even in adolescence, it is less likely that the SUDs with a late age of onset are strongly influenced by this genetic liability. Although the NE liability contributes to comorbidity between INT disorders and SUDs, research also suggests that stress, particularly chronic stress over time, and the neurobiological effects of chronic stress response systems (e.g., on HPA system functioning) plays an important role in the comorbidity of internalizing disorders and SUDs (Brady \& Sinha, 2005).

\subsection{Other Explanations for Comorbidity}

Other explanations for the comorbidity of SUDs with other disorders are also supported by research. One commonly posited explanation is directional or reciprocal causality in which one disorder or the consequences of the disorder (e.g., neuroadaptations associated with chronic drug use) cause a second disorder, and these causal links may be reciprocal. Several lines of 
research support this explanation. First, internalizing (e.g., MDD, PD) and externalizing disorders (e.g., CD, ODD) have been found to prospectively predict SUDs and vice versa (Breslau, Novak, \& Kessler, 2004; Fergusson, Boden, \& Horwood, 2009; Goodman \& Capitman, 2000; Greenfield et al., 1998; Kushner, Sher, \& Erickson, 1999; Marmorstein \& Iacono, 2011; Marmorstein, Iacono, \& Malone, in press; Rao et al., 2000). These findings are consistent with directional causality, but findings of directionality do not necessarily imply causation and also do not rule out a common liability explanation for comorbidity.

Second, when depressive or anxiety disorders precede SUDs, a common explanation is the "self-medication" theory, which proposes that individuals begin using substances to "treat" symptoms of a primary disorder. For example, nicotine dependence co-occurs with depression, and smoking results in marked reductions in brain levels of monoamine oxidase A (MAO-A; Fowler et al., 1996), an enzyme that degrades serotonin and norepinephrine. MAO inhibitors are antidepressant drugs that block this process (Adli et al., 2008), suggesting that smoking, too, may have an antidepressant effect. The self-medication theory, though, is challenged by findings that SUDs often precede internalizing disorders (Fergusson, et al., 2009; Marmorstein, et al., 2010; Rao et al., 2000) and by a study that used biometric modeling to compare etiological models for the comorbidity of nicotine dependence and depression and found support for a correlated or shared familial liability (perhaps a common NE liability) rather than for one disorder leading to the other (Johnson, Rhee, Chase, \& Breslau, 2004).

Third, longitudinal studies of adolescent and young adults have found that episodes of depression and substance use tend to occur in close temporal proximity (Fergusson, et al., 2009; Rao et al., 2000). This research may indicate bidirectional influence of symptoms of the comorbid disorders but may also be explained by common environmental triggers, greater use of 
substances when feeling depressed among individuals who have a common genetic liability for both disorders, or negative consequences of one of the disorders (e.g., failing grades, strained interpersonal relationships) increasing symptoms of the other disorder. Fourth, when SUDs are comorbid with another condition, SUD symptoms tend to be more severe (Conway et al., 2006; Grant et al., 1996), durations of remission and time to relapse are shorter (Greenfield et al., 1998; Hasin et al., 2002), and treatments are less effective unless there is conjunctive treatment for the comorbid disorder (Myrick \& Brady, 2003). These findings may indicate that the comorbid disorder exacerbates (or is causally linked to) SUD symptoms, but these findings may also suggest a common genetic liability that underlies more severe, chronic, treatment-resistant symptoms of both disorders.

In summary, these lines of research are consistent with directional and reciprocal causality but are also compatible with a common liabilities model. These two explanations for comorbidity are not mutually exclusive, and both likely contribute to comorbidity in complex ways. To be more specific, the presence of a genetic liability does not determine that a disorder will develop but rather increases the likelihood that a disorder will develop given the presence of other genetic and environmental risk factors, which may include other psychiatric disorders. For example, a common genetic liability for NE increases the likelihood of developing both AUD and social anxiety disorder, and the liability may be expressed first as social anxiety symptoms which in turn casually contribute to the liability being expressed as alcohol dependence. The causality explanation is also likely complicated and mediated by changes in environmental risks (e.g., unemployment, strained interpersonal relationships, unhealthy compensatory strategies used to manage the primary disorder) and changes in the individual that are probably genetically influenced to some degree (e.g., changes in brain structures and functions, cognitive processes). 
Both common liabilities and causal relationships between comorbid disorders likely contribute to the noted strong correlations between the INT and EXT factors and the subfactors and among the individual disorders. Therefore, the hierarchical common liabilities model is not intended to be exhaustive or exclusive of other explanations for comorbidity but rather to integrate important findings about phenotypic covariance, genetics, environmental influences, biological systems, and developmental changes.

\section{Conclusion}

\subsection{Summary}

The etiology of mental disorders is increasingly understood to involve many interacting genes and environmental factors. Individual pathways of risk begin with general genetic liabilities that, throughout development, interact with environmental factors and other genetic factors and result in increased likelihood of developing some mental disorders and decreased likelihood of developing other disorders. This chapter provided a review of research on comorbidity with SUDs and proposed an integrative hierarchical model based on phenotypic covariance and latent genetic liabilities to explain observed patterns of disorder co-occurrence. The highest order factor, NE, increases risk for all INT and EXT mental disorders included in Figure 1. In other words, individuals with these mental disorders are likely to share, to varying degrees, the genetic liability for NE, with any particular disorder they develop shaped by the presence of other genes (e.g., genes affecting liability for disorders associated with BD) and environmental factors. The comorbidity of disorders increases as the number of shared genetic liabilities and shared environmental influences increases. Disorders falling in the same INT/EXT spectra have high comorbidity because individuals with these disorders are likely to inherit not 
only the NE liability but also a more specific genetic liability that is shared by disorders in the spectrum.

Further differentiation occurs because each disorder in the model is also influenced by specific effects that are unique to the disorder and account for the development of different disorders among individuals who share these higher order liabilities. These specific genetic and environmental effects differ in nature across the disorders, and the proportion of genetic to environmental influence unique to a disorder varies from one disorder to another. Using multivariate twin modeling, Kendler et al. (2003) found that disorder-specific loadings for unique (i.e., not shared among family members) environmental influences on these common mental disorders were substantial, whereas environmental influences shared among family members were very small. The magnitude of disorder-specific genetic loadings varied across disorders with substantial loadings found only for alcohol dependence and drug abuse/dependence, suggesting that these specific effects are largely environmental. As follows, genetic and environmental influences at the higher levels of the hierarchy explain comorbidity among different disorders and specific genetic and environmental influences at the lowest level of the hierarchy account for multifinality and the etiology of individual disorders.

\subsection{Limitations}

Despite the breadth and comprehensiveness of this model, it does not attempt to account fully for mental disorder co-occurrence or to exclude other mechanisms that may also contribute to comorbidity (e.g., one disorder causing the other). The model focuses on common disorders that have typically been assessed in epidemiologic and behavior genetics investigations that examine the underlying structure of psychopathology and thus are known to have shared covariance with other INT or EXT disorders. Consequently, some disorders (e.g., posttraumatic 
stress disorder, personality disorders besides ASPD, psychotic disorders, bipolar disorders) are not included in the model. In addition, the model does not distinguish among different illicit drug use disorders. Further, relevant moderating variables, such as gender, ethnicity, and family history of psychopathology, are not included in the model but would improve the specificity of the model for understanding comorbidity in distinct groups and under various conditions. It is important to note, though, that although there are well-known gender differences in the mean level of EXT and INT attributes, many studies find no gender effects pointing to differences in the etiology of mental disorders, for example, in the hierarchical factor structures of psychopathology (Krueger, 1999b), the structure of genetic and environmental influences on externalizing disorders (e.g., Hicks et al., 2007; Kendler, Prescott et al., 2003), heritability of disorders (Heath et al., 1997; Sullivan et al., 2000), and relationships between personality or temperament and psychopathology (Oldehinkel et al., 2004).

\subsection{Implications and Future Directions}

The goal of this chapter was to propose an integrative, research-derived model that provides an organizational framework for guiding future research on the origins of comorbid mental disorders. Although the structure and components of the model are all empirically derived, some components have more empirical support than others. The liability to persistent negative thinking, for example, is certainly consistent with theoretical models of depression and anxiety and findings of characteristic negative thinking patterns in depressed and anxious individuals, but almost no research has investigated the genetic basis of these negative thinking patterns, the genetic covariation between these thinking patterns and internalizing psychopathology, or endophenotypes related to these constructs. Better phenotypic characterization of the behaviors, traits, and cognitive processes associated with these genetically 
influenced liabilities and research on the genetic covariation between these liabilities and psychopathology will advance our understanding of the structure underlying comorbidity of mental disorders. These broad phenotypes can then be used in the search for specific genes associated with psychopathology and, when studied in conjunction with specific disorders, will ultimately lead to delineation of the etiology and biological processes shared among comorbid disorders and biological processes that distinguish mental disorders. In addition, research on endophenotypes for the liabilities is lacking and is important for linking the neurobiological, genetic, and phenotypic findings to better understand the diverse, complex, interacting systems that contribute to comorbidity. Studies that use an interdisciplinary approach to investigating the interplay of genetics, neurobiological systems, and environmental factors will be key to understanding comorbidity.

This model can also be used to guide research on the genetic and environmental factors underlying psychopathology more broadly defined. Feinstein (1970), who coined the term comorbidity, originally described a broad construct that referred to comorbidity not just among medical disorders but also among symptoms of disorders and other clinical phenomena that do not meet criteria for disease status (Feinstein, 1970; Krueger \& Markon, 2006). Krueger (2002, 2005) and others have provided evidence that psychopathology is best conceptualized along continuous dimensions, rather than as discrete entities (Krueger, et al., 2005; Krueger \& Piasecki, 2002). In fact, psychopathology researchers have debated use of the term "comorbidity" to describe mental disorders and how to best conceptualize the observed cooccurrence of mental disorders. Lilienfeld et al. (1994) and others discussed concerns that the term comorbidity inappropriately reifies psychopathology as defined by discrete, wellunderstood categorical diagnoses with distinct etiologies rather than conceptualizing it in a 
dimensional framework (Lilienfeld, Waldman, \& Israel, 1994; Meehl, 2001), while others have argued that the concept of comorbidity is useful even when categories do not have clearly distinct etiologies (Spitzer, 1994). Krueger and Markon (2006) raise the related concern that cooccurrence of two legitimate diagnoses in a single individual should be distinguished from correlation or covariation of diagnoses in a group of people (Krueger \& Markon, 2006).

Regardless of whether or not the term "comorbidity" and discrete diagnostic categories are used, the empirical evidence and the proposed common liability model suggest that advancing our understanding of the origins of comorbidity (or "co-occurrence") requires broadening our conceptualization of this phenomenon to include not only diagnoses or dimensional measures of psychopathology but also related personality traits, behavioral tendencies, and neurobiological systems. It requires studying these broad factors from a developmental perspective in order to understand developmental differences in the expression of genetic liabilities, the progression of risk from early appearances of problems to impairing psychopathology, and how genetic and environmental interplay affects the course of comorbid disorder development. Finally, it implies that efforts to find genes for SUDs and related psychopathology would do well to capitalize on what we know about comorbidity. That is, rather than only trying to find genes for specific SUDs, efforts directed at finding genes associated with the covariance among disorders are also needed. Because behavior genetic studies have shown that the latent traits underlying this covariance are more heritable than the individual characteristics comprising it, gene finding approaches targeting the latent traits have strong payoff potential. 


\section{Related Chapters}

4. The Neurobiology of Reward and Stress and Its Relevance for Understanding Drug Seeking and Dependence Symptomatology

6. Genetic Epidemiology and Molecular Genetics

19. Substance Use, Personality, and Emotion Regulation

20. Cognitive Processes in Alcohol and Drug Abuse

27. Childhood Externalizing Disorders

29. Anxiety and Mood Disorders 


\section{Acknowledgments}

Preparation of this chapter was supported by the National Institutes on Drug Abuse (DA 13240, DA 05147, DA 024417), Alcohol Abuse and Alcoholism (AA 09367, AA 11886), and Mental Health (MH66140), and the National Cancer Institute (through DA 024417). 


\section{References}

Abramson, L. Y., Metalsky, G. I., \& Alloy, L. B. (1989). Hopelessness depression: A theorybased subtype of depression. Psychological Review, 96, 358-372.

Abramson, L. Y., Seligman, M. E. P., \& Teasdale, J. (1978). Learned Helplessness in Humans: Critique and Reformulation. Journal of Abnormal Psychology, 87, 49-74.

Adli, M., Pilhatsch, M., Bauer, M., Koberle, U., Ricken, R., Janssen, G., et al. (2008). Safety of high-intensity treatment with the irreversible monoamine oxidase inhibitor tranylcypromine in patients with treatment-resistant depression. Pharmacopsychiatry, 41, 252-257.

Agrawal, A., Jacobson, K., Prescott, C., \& Kendler, K. S. (2004). A Twin Study of Personality and Illicit Drug Use and Abuse/Dependence. Twin Research, 7, 72-81.

Agrawal, A., \& Lynskey, M. T. (2006). The genetic epidemiology of cannabis use, abuse, and dependence. Addiction, 101, 801-812.

Agrawal, A., Lynskey, M. T., Bucholz, K. K., Martin, N. G., Madden, P. A., \& Heath, A. C. (2007). Contrasting models of genetic comorbidity for cannabis and other illicit drugs in adult Australian twins. Psychological Medicine, 37, 49-60.

Agrawal, A., Neale, M. C., Prescott, C. A., \& Kendler, K. S. (2004a). Cannabis and other illicit drugs: comorbid use and abuse/dependence in males and females. Behavior Genetics, 34, 217-228.

Agrawal, A., Neale, M. C., Prescott, C. A., \& Kendler, K. S. (2004b). A twin study of early cannabis use and subsequent use and abuse/dependence of other illicit drugs. Psychological Medicine, 34, 1227-1237. 
Aldao, A., \& Nolen-Hoeksema, S. (2010). Specificity of cognitive emotion regulation strategies: A transdiagnostic examination. Behaviour Research and Therapy, 48(10), 974-983.

Alloy, L. B., Abramson, L. Y., Gibb, B. E., Crossfield, A. G., Pieracci, A. M., Spasojevic, J., et al. (2004). Developmental antecedents of cognitive vulnerability to depression: Review of findings from the cognitive vulnerability to depression project. Journal of Cognitive Psychotherapy, 18, 115-133.

Anderson, J. C., Williams, S., McGee, R., \& Silva, P. A. (1987). DSM-III Disorders in preadolescent children. Prevalence in a large sample from the general population. Archives of General Psychiatry 44, 69-76.

Angold, A., Costello, E. J., \& Erkanli, A. (1999). Comorbidity. Journal of Child Psychology and Psychiatry, 40, 57-87.

Anokhin, A. P., Golosheykin, S., \& Heath, A. C. (2007). Genetic and environmental influences on emotion-modulated startle reflex: A twin study. Psychophysiology, 44, 106-112.

Anthony, J. C., \& Lonigan, C. J. (2002). An affect-based, hierarchical model of temperament and its relations with internalizing symptomatology. Journal of Clinical Child \& Adolescent Psychology, 31, 480-490.

Armstrong, T. D., \& Costello, J. (2002). Community studies on adolescent substance use, abuse, or dependence and psychiatric comorbidity. Journal of Consulting and Clinical Psychology, 70, 1224-1239.

Aseltine, R. H., Gore, S., \& Colten, M. E. (1998). The co-occurrence of depression and substance abuse in late adolescence. Development and Psychopathology, 10, 549-570. 
Bachanas, P. J., \& Kaslow, N. J. (2001). Depressive Disorders. In J. C. Conoley, A. M. LaGreca, \& J. N. Hughes (Eds.), Handbook of psychological services for children and adolescents (pp. 323-352). New York: Oxford University Press.

Barlow, D. H. (1991). The nature of anxiety: Anxiety, depression, and emotional disorders. In R. M. Rapee \& D. H. Barlow (Eds.), Chronic anxiety: Generalized anxiety disorder and mixed anxiety-depression (pp. 1-28). New York: Guilford Press.

Bartels, M., van Beijsterveldt, C., Derks, E. M., Stroet, T. M., Polderman, T. J., Hudziak, J. J., et al. (2007). Young Netherlands Twin Register (Y-NTR): A longitudinal multiple informant study of problem behavior. Twin Research and Human Genetics, 10, 3-11.

Bechara, A. (2005). Decision making, impulse control and loss of willpower to resist drugs: a neurocognitive perspective. Nature Neuroscience, 8, 1458-1463.

Beck, A. T. (1967). Depression: Clinical, experimental, and theoretical aspects. New York: Hoeber.

Beck, A. T. (1976). Cognitive therapy and emotional disorders. New York: International Universities Press.

Beck, A. T., \& Clark, D. A. (1997). An Information processing model of anxiety: Automatic and strategic processes. Behaviour Research \& Therapy, 35, 49-58.

Bergen, S. E., Gardner, C. O., Kendler, K. S., Bergen, S. E., Gardner, C. O., \& Kendler, K. S. (2007). Age-related changes in heritability of behavioral phenotypes over adolescence and young adulthood: a meta-analysis. Twin Research \& Human Genetics: The Official Journal of the International Society for Twin Studies, 10, 423-433.

Bienvenu, O., Hettema, J. M., Neale, M. C., Prescott, C. A., \& Kendler, K. S. (2007). Low extraversion and high neuroticism as indices of genetic and environmental risk for social 
phobia, agoraphobia, and animal phobia. American Journal of Psychiatry, 164, 17141721.

Birley, A. J., Gillespie, N. A., Heath, A. C., Sullivan, P. F., Boomsma, D. I., \& Martin, N. G. (2006). Heritability and nineteen-year stability of long and short EPQ-R Neuroticism scales. Personality and Individual Differences, 40, 737-747.

Block, J. H., Gjerde, P. F., \& Block, J. H. (1991). Personality Antecedents of Depressive Tendencies in 18-Year-Olds: A Prospective Study. Journal of Personality and Social Psychology, 60, 726-738.

Bradley, B. P., Mogg, K., White, J., Groom, C., \& de Bono, J. (1999). Attentional bias for emotional faces in generalized anxiety disorder. British Journal of Clinical Psychology, 38(3), 267-278.

Brady, K. T., \& Sinha, R. (2005). Co-Occurring Mental and Substance Use Disorders: The Neurobiological Effects of Chronic Stress. American Journal of Psychiatry, 162, 14831493.

Breslau, N., Novak, S. P., \& Kessler, R. C. (2004). Psychiatric disorders and stages of smoking. Biological Psychiatry, 55(1), 69-76.

Brouwer, J. P., Appelhof, B. C., van Rossum, E. F., Koper, J. W., Fliers, E., Huyser, J., et al. (2006). Prediction of treatment response by HPA-axis and glucocorticoid receptor polymorphisms in major depression. Psychoneuroendocrinology, 31, 1154-1163.

Burt, S. A., Krueger, R. F., McGue, M., \& Iacono, W. G. (2001). Sources of covariation among attention-deficit/hyperactivity disorder, oppositional defiant disorder, and conduct disorder: the importance of the shared environment. Journal of Abnormal Psychology, $110,516-525$. 
Button, T. M., Hewitt, J. K., Rhee, S. H., Young, S. E., Corley, R. P., \& Stallings, M. C. (2006). Examination of the causes of covariation between conduct disorder symptoms and vulnerability to drug dependence. Twin Research \& Human Genetics, 9, 38-45.

Button, T. M., Rhee, S. H., Hewitt, J. K., Young, S. E., Corley, R. P., \& Stallings, M. C. (2007). The role of conduct disorder in explaining the comorbidity between alcohol and illicit drug dependence in adolescence. Drug and Alcohol Dependence, 87, 46-53.

Carlson, S. R., Katsanis, J. K., Iacono, W. G., \& McGue, M. (1997). Emotional modulation of the startle reflex in twins: Preliminary findings. Biological Psychology, 46, 235-246.

Carlson, S. R., McLarnon, M. E., \& Iacono, W. G. (2007). P300 amplitude, externalizing psychopathology, and earlier- versus later-onset substance-use disorder. Journal of Abnormal Psychology, 116, 565-577.

Caspi, A., Henry, B., McGee, R. O., Moffitt, T. E., \& Silva, P. A. (1995). Temperamental origins of child and adolescent behavior problems: from age three to age fifteen. Child Development, 66, 55-68.

Caspi, A., Moffitt, T. E., Newman, D. L., \& Silva, P. A. (1996). Behavioral observations at age 3 years predict adult psychiatric disorders. Archives of General Psychiatry, 53, 1033-1039.

Chassin, L., Fora, D. B., \& King, K. M. (2004). Trajectories of alcohol and drug use and dependence from adolescence to adulthood: the effects of familial alcoholism and personality. Journal of Abnormal Psychology, 113, 483-498.

Chorpita, B. F., \& Daleiden, E. L. (2002). Tripartite Dimensions of Emotion in a Child Clinical Sample: Measurement Strategies and Implications for Clinical Utility. Journal of Consulting and Clinical Psychology, 70, 1150-1160. 
Cicchetti, D., \& Rogosch, F. (1996). Equifinality and multifinality in developmental psychopathology. Development and Psychopathology, 8, 597-600.

Cicchetti, D., \& Tucker, D. (1994). Development and self-regulatory structures of the mind. Development and Psychopathology, 6, 533-550.

Clark, L. A., \& Watson, D. (1991). Tripartite model of anxiety and depression: Psychometric evidence and taxonomic implications. Journal of Abnormal Psychology, 103, 103-116.

Clark, L. A., Watson, D., \& Reynolds, S. (1995). Diagnosis and classification of psychopathology: challenges to the current system and future directions. Annual Review of Psychology, 46, 121-153.

Clarke, T. K., Treutlein, J., Zimmermann, U. S., Kiefer, F., Skowronek, M. H., Rietschel, M., et al. (2008). HPA-axis activity in alcoholism: Examples for a gene-environment interaction. Addiction Biology, 13, 1-14.

Cloninger, C. R., Sigvardsson, S., \& Bohman, M. (1988). Childhood personality predicts alcohol abuse in young adults. Alcoholism, 12, 494-505.

Cole, P., M., Michel, M., K., \& Teti, L. O. (1994). The development of emotion regulation and dysregulation: A clinical perspective. Monographs of the Society for Research in Child Development, 59, 73-100.

Comings, D. E., Wu, S., Rostamkhani, M., McGue, M., Iacono, W. G., \& MacMurray, J. P. (2002). Association of the Muscarinic Cholinergic 2 Receptor (CHRM2) Gene With Major Depression in Women. American Journal of Medical Genetics, 114, 527-529.

Compas, B. E., Conner-Smith, J., \& Jaser, S. S. (2004). Temperament, stress reactivity, and coping: Implications for depression in childhood and adolescence. Journal of Clinical Child \& Adolescent Psychology, 33, 21-31. 
Curry, A., Latkin, C., Davey-Rothwell, M., Curry, A., Latkin, C., \& Davey-Rothwell, M. (2008). Pathways to depression: the impact of neighborhood violent crime on inner-city residents in Baltimore, Maryland, USA. Social Science \& Medicine, 67, 23-30.

Cuthbert, B. N., Lang, P., J., Strauss, C., Drobes, D., Patrick, C. J., \& Bradley, M. M. (2003). The psychophysiology of anxiety disorder: Fear memory imagery. Psychophysiology, 40, 407-422.

Derefinko, K. J., \& Lynam, D. R. (2006). Convergence and divergence among self-report psychopathy measures: a personality-based approach. Journal of Personality Disorders, 20, 261-280.

Derryberry, D., \& Rothbart, M. K. (1988). Affect, arousal, and attention as components of temperament. Journal of Personality and Social Psychology, 55, 958-966.

Derryberry, D., \& Rothbart, M. K. (1997). Reactive and effortful processes in the organization of temperament. Development and Psychopathology, 9, 633-652.

Dick, D. M., Aliev, G., Wang, J. C., Grucza, R. A., Schuckit, M., \& al., e. (2008). Using dimensional models of externalizing psychopathology to aid in gene identification. Archives of General Psychiatry, 65, 310-318.

Dick, D. M., Viken, R. J., Kaprio, J., Pulkkinen, L., \& Rose, R. J. (2005). Understanding the covariation among childhood externalizing symptoms: genetic and environmental influences on conduct disorder, attention deficit hyperactivity disorder, and oppositional defiant disorder symptoms. Journal of Abnormal Child Psychology, 33, 219-229.

Duncan, L. E., \& Keller, M. C. (2011). A critical review of the first 10 years of candidate geneby-environment interaction research in psychiatry. American Journal of Psychiatry, 168, 1041-1049. 
Eaves, L., Silberg, J., Erkanli, A., Eaves, L., Silberg, J., \& Erkanli, A. (2003). Resolving multiple epigenetic pathways to adolescent depression. Journal of Child Psychology \& Psychiatry \& Allied Disciplines, 44, 1006-1014.

Ehringer, M. A., Rhee, S. H., Young, S., Corley, R., \& Hewitt, J. K. (2006). Genetic and environmental contributions to common psychopathologies of childhood and adolescence: A study of twins and their siblings. Journal of Abnormal Child Psychology, $34,1-17$.

Eisenberg, N., Cumberland, A., Spinrad, T. L., Fabes, R. A., Shepard, S. A., Reiser, M., et al. (2001). The relations of regulation and emotionality to children's externalizing and internalizing problem behavior. Child Development, 72, 1112-1134.

Eley, T. C., Bolton, D., O’Connor, T. G., Perrin, S., Smith, P., \& Plomin, R. (2003). A twin study of anxiety-related behaviours in pre-school children. Journal of Child Psychology and Psychiatry, 44, 945-960.

Eley, T. C., \& Brown, T. A. (2004). Phenotypic and genetic/environmental structure of anxiety sensitivity in adolescents. Behavior Genetics, 34, 637.

Eley, T. C., Gregory, A. M., Clark, D. M., \& Ehlers, A. (2007). Feeling anxious: a twin study of panic/somatic ratings, anxiety sensitivity and heartbeat perception in children. Journal of Child Psychology and Psychiatry, 48, 1184-1191.

Eley, T. C., Gregory, A. M., Lau, J. Y., McGuffin, P., Napolitano, M., Rijsdijk, F. V., et al. (2008). In the face of uncertainty: A twin study of ambiguous information, anxiety and depression in children. Journal of Abnormal Child Psychology, 36, 55-65. 
Elkins, I. J., King, S. M., McGue, M., \& Iacono, W. G. (2006). Personality traits and the development of nicotine, alcohol, and illicit drug disorders: Prospective links from adolescence to young adulthood. Journal of Abnormal Psychology, 115, 26-39.

Elkins, I. J., McGue, M., Malone, S., \& Iacono, W. G. (2004). The effect of parental alcohol and drug disorders on adolescent personality. American Journal of Psychiatry, 161, 670-676.

Ellis, J. A., Olsson, C. A., Moore, E., Greenwood, P., Van De Ven, M. O. M., \& Patton, G. C. (2011). A role for the DRD4 Exon III VNTR in modifying the association between nicotine dependence and neuroticism. Nicotine \& Tobacco Research, 13(2), 64-69.

Everaert, J., Koster, E. H. W., \& Derakshan, N. (2012). The combined cognitive bias hypothesis in depression. Clinical Psychology Review, 32(5), 413-424.

Eysenck, M. W. (1992). Anxiety: The cognitive perspective. Hove, UK: Erlbaum Ltd.

Eysenck, M. W. (1997). Anxiety and cognition: A unified theory. Hove, UK: Erlbaum Ltd.

Eysenck, S. B. G., Eysenck, H. J., \& Barrett, P. (1985). A revised version of the psychoticism scale. Personality and Individual Differences, 6, 21-29.

Fanous, A., Gardner, C. O., Prescott, C. A., Cancro, R., \& Kendler, K. S. (2002). Neuroticism, major depression and gender: a population-based twin study. Psychological Medicine, 32, 719-728.

Fanous, A. H., Neale, M. C., Aggen, S. H., \& Kendler, K. S. (2007). A longitudinal study of personality and major depression in a population-based sample of male twins. Psychological Medicine, 37, 1163-1172.

Fava, M., Hwang, I., Rush, A. J., Sampson, N., Walters, E. E., \& Kessler, R. C. (2010). The importance of irritability as a symptom of major depressive disorder: Results from the National Comorbidity Survey replication. Molecular Psychiatry, 15(8), 856-867. 
Feinstein, A. R. (1970). The pre-therapeutic classification of co-morbidity in chronic disease. Journal of Chronic Diseases, 23, 455-468.

Fergusson, D. M., Boden, J. M., \& Horwood, J. (2009). Tests of causal links between alcohol abuse or dependence and major depression. Archives of General Psychiatry, 66, 206-266.

Firk, C., Markus, C. R., Firk, C., \& Markus, C. R. (2007). Review: Serotonin by stress interaction: a susceptibility factor for the development of depression? Journal of Psychopharmacology, 21, 538-544.

Fleming, J. E., Offord, D. R., \& Boyle, M. H. (1989). Prevalence of childhood and adolescent depression in the community: Ontario Child Health Study. British Journal of Psychology, $28,647-654$.

Florez, G., Saiz, P., Garcia-Portilla, P., Álvarez, S., Nogueíras, L., Morales, B., et al. (2008). Association between the Stin2 VNTR polymorphism of the serotonin transporter gene and treatment outcome in alcohol-dependent patients. Alcohol and Alcoholism, 43, 516522.

Forbes, E. E., Miller, A., Cohn, J. F., Fox, N. A., \& Kovacs, M. (2005). Affect-modulated startle in adults with childhood-onset depression: Relations to bipolar course and number of lifetime depressive episodes Psychiatry Research, 134, 11-25.

Fowler, J. S., Volkow, N. D., Wang, G. J., Pappas, N., Logan, J., Shea, C., et al. (1996). Brain monoamine oxidase A inhibition in cigarette smokers. Proceedings of the National Academy of Sciences of the United States of America 93, 14065-14069.

Fox, N. A., \& Pine, D. S. (2012). Temperament and the emergence of anxiety disorders. Journal of the American Academy of Child \& Adolescent Psychiatry, 51(2), 125-128. 
Fu, Q., Heath, A. C., Bucholz, K. K., Nelson, E., Goldberg, J., Lyons, M. J., et al. (2002). Shared genetic risk of major depression, alcohol dependence, and marijuana dependence: Contribution of antisocial personality disorder in men. Archives of General Psychiatry, 59, 1125-1132.

Garakani, A., Mathew, S. J., \& Charney, D. S. (2006). Neurobiology of anxiety disorders and implications for treatment. Mount Sinai Journal of Medicine, 73, 941-949.

Gershuny, B. S., \& Sher, K. J. (1998). The relation between personality and anxiety: Findings from a 3-year prospective study. Journal of Abnormal Psychology, 107, 252-262.

Gillespie, N. A., \& Martin, N. G. (2006). Neuroticism as a Genetic Marker for Mood and Anxiety. In T. Canli (Ed.), Biology of personality and individual differences (pp. 225250). New York, NY: Guilford Press.

Gladstone, G. L., Parker, G. B., Gladstone, G. L., \& Parker, G. B. (2006). Is behavioral inhibition a risk factor for depression? Journal of Affective Disorders, 95, 85-94.

Goldman, D., Oroszi, G., \& Ducci, F. (2005). The genetics of addictions: uncovering genes. Nature Reviews Genetics, 6, 521-532.

Goodman, E., \& Capitman, J. (2000). Depressive symptoms and cigarette smoking among teens. Pediatrics, 106, 748-755.

Gotlib, I. H., \& Joormann, J. (2010). Cognition and depression: Current status and future directions. Annual Review of Clinical Psychology, 6, 285-312.

Gottesman, I. I., \& Gould, T. D. (2003). The endophenotype concept in psychiatry: etymology and strategic intentions. American Journal of Psychiatry, 160, 636-645.

Gralinski, J. H., \& Kopp, C. B. (1993). Everyday rules for behavior: Mothers' requests to young children. Developmental Psychology, 29, 573-584. 
Grant, B. F., \& Dawson, D. A. (1997). Age at onset of alcohol use and its association with DSMIV alcohol abuse and dependence: Results from the national Longitudinal Alcohol Epidemiologic Survey. Journal of Substance Abuse, 9, 103-110.

Grant, J. D., Scherrer, J. F., Lynskey, M. T., Lyons, M. J., Eisen, S. A., \& al., e. (2006). Adolescent alcohol use is a risk factor for adult alcohol and drug dependence: evidence from a twin design. Psychological Medicine, 36, 109-118.

Gray, J. A. (1972). the psychophysiological basis of introversion-extraversion: A modification of Eysenck's theory. In V. D. Nebylitsyn \& J. A. Gray (Eds.), The biological basis of individual behaviour (pp. 182-205). San Diego, CA: Academic Press.

Gray, J. A. (1975). Elements of a Two-Process Theory of Learning. New York: Academic.

Gray, J. A. (1981). A critique of Eysenck's theory of personality. In H. J. Eysenck (Ed.), A model for personality (pp. 246-276). Berlin: Springer-Verlag.

Greenfield, S., Weiss, R. Nuenz, L., Vagge, L., Kelly, J., Bellow, L., Michael, J. (1998). The effect of depression on return to drinking: A prospective study. Archives of General Psychiatry, 55, 259-265.

Gregory, A. M., Rijsdijk, F. V., Lau, J. Y., Napolitano, M., McGuffin, P., Eley, T. C., et al. (2007). Genetic and environmental influences on interpersonal cognitions and associations with depressive symptoms in 8-year-old twins. Journal of Abnormal Psychology, 116, 762-775.

Grekin, E. R., Sher, K. J., \& Wood, P. K. (2006). Personality and substance dependence symptoms: modeling substance-specific traits. Psychology of Addictive Behaviors, 20, 415-424. 
Gross, J. J., \& Thompson, R. A. (2007). Emotion Regulation: Conceptual Foundations. In J. J. Gross (Ed.), Handbook of emotion regulation. (pp. 3-24). New York, NY US: Guilford Press.

Haas, B. W., Canli, T., Haas, B. W., \& Canli, T. (2008). Emotional memory function, personality structure and psychopathology: a neural system approach to the identification of vulnerability markers. Brain Research Reviews, 58, 71-84.

Hankin, B. L., Badanes, L. S., Abela, J. R. Z., \& Watamura, S. E. (2010). Hypothalamicpituitary-adrenal axis dysregulation in dysphoric children and adolescents: Cortisol reactivity to psychosocial stress from preschool through middle adolescence. Biological Psychiatry, 68(5), 484-490.

Hansell, N. K., Wright, M. J., Medland, S. E., Davenport, T. A., Wray, N. R., Martin, N. G., et al. (2012). Genetic co-morbidity between neuroticism, anxiety/depression and somatic distress in a population sample of adolescent and young adult twins. Psychological Medicine, 42(6), 1249-1260.

Hasin, D. S., Liu, X., Nunes, E., McCloud, S., Samet, S., \& Endicott, J. (2002). Effects of major depression on remission and relapse of substance dependence. Archives of General Psychiatry, 59, 375-380.

Heath, A. C., Bucholz, K. K., Madden, P. A., Dinwiddie, S. H., Slutske, W. S., Bierut, L. J., et al. (1997). Genetic and environmental contributions to alcohol dependence risk in a national twin sample: consistency of findings in women and men. Psychological Medicine, 27, $1381-1396$. 
Hettema, J. M., Kuhn, J. W., Prescott, C. A., Kendler, K. S., Hettema, J. M., Kuhn, J. W., et al. (2006). The impact of generalized anxiety disorder and stressful life events on risk for major depressive episodes. Psychological Medicine, 36, 789-795.

Hettema, J. M., Neale, M. C., Myers, J. M., Prescott, C. A., \& Kendler, K. S. (2006). A population-based twin study of the relationship between neuroticism and internalizing disorders. American Journal of Psychiatry, 163, 857-864.

Hettema, J. M., Prescott, C. A., \& Kendler, K. S. (2004). Genetic and environmental sources of covariation between generalized anxiety disorder and neuroticism American Journal of Psychiatry, 161, 1581-1587.

Hettema, J. M., Prescott, C. A., Myers, J. M., Neale, M. C., \& Kendler, K. S. (2005). The structure of genetic and environmental risk factors for anxiety disorders in men and women. Archives of General Psychiatry, 62, 182-189.

Hicks, B. M., Bernat, E., Malone, S. M., Iacono, W. G., Patrick, C. J., Krueger, R. F., et al. (2007a). Genes mediate the association between P3 amplitude and externalizing disorders. Psychophysiology, 44, 98-105.

Hicks, B. M., Blonigen, D. M., Kramer, M. D., Krueger, R. F., Patrick, C. J., \& al, e. (2007b). Gender differences and developmental change in externalizing disorders from late adolescence to early adulthood: A longitudinal twin study. Journal of Abnormal Psychology, 116, 433-447.

Hicks, B.M., Foster, K.T., Iacono, W.G., \& McGue, M. (2013). Genetic and environmental influences on the familial trainsmission of externalizing disorders in adoptive and twin offspring. JAMA Psychiatry, In Press. 
Hicks, B. M., Krueger, R. F., Iacono, W. G., McGue, M., \& Patrick, C. J. (2004). Family transmission and heritability of externalizing disorders: a twin-family study. Archives of General Psychiatry, 61, 922-928.

Hicks, B. M., \& Patrick, C. J. (2006). Psychopathy and negative emotionality: Analyses of suppressor effects reveal distinct relations with emotional distress, fearfulness, and angerhostility. Journal of Abnormal Psychology, 115, 276-287.

Hicks, B. M., Schalet, B. D., Malone, S. M., Iacono, W. G., \& McGue, M. (2011). Psychometric and genetic architecture of substance use disorder and behavioral disinhibition measures for gene association studies. Behavior Genetics, 41(4), 459-475.

Hipwell, A. E., Murray, L., Ducournau, P., \& Stein, A. (2005). The effects of maternal depression and parental conflict on children's peer play. Child: Care, Health and Development, 31, 11-23.

Hirata, Y., Zai, C. C., Nowrouzi, B., Beitchman, J. H., \& Kennedy, J. L. (2013). Study of the Catechol-O-Methyltransferase (COMT) gene with high aggression in children. Aggressive Behavior, 39(1), 45-51.

Hiroi, N., \& Agatsuma, S. (2005). Genetic susceptibility to substance dependence. Molecular Psychiatry, 10, 336-344.

Hirsch, C. R., Clark, D. M., \& Mathews, A. (2006). Imagery and Interpretations in Social Phobia: Support for the Combined Cognitive Biases Hypothesis. Behavior Therapy, $37(3), 223-236$.

Hirshfeld-Becker, D. R., Biederman, J., Henin, A., Faraone, S. V., Davis, S., Harrington, K., et al. (2007). Behavioral inhibition in preschool children at risk is a specific predictor of 
middle childhood social anxiety: A five-year follow-up. Journal of Developmental and Behavioral Pediatrics, 28(3), 225-233. doi: 10.1097/01.DBP.0000268559.34463.d0

Hofmann, S. G., Moscovitch, D. A., \& Kim, H. J. (2006). Autonomic correlates of social anxiety and embarrassment in shy and non-shy individuals. International Journal of Psychophysiology, 61, 134-142.

Hofmann, S. G., Sawyer, A. T., Fang, A., \& Asnaani, A. (2012). Emotion dysregulation model of mood and anxiety disorders. Depression and Anxiety, 29(5), 409-416.

Holmes, A. (2008). Genetic variation in cortico-amygdala serotonin function and risk for stressrelated disease. Neuroscience \& Biobehavioral Reviews, 32, 1293-1314.

Hopfer, C. J., Crowley, T. J., \& Hewitt, J. K. (2003). Review of twin and adoption studies of adolescent substance use. Journal of the American Academy of Child \& Adolescent Psychiatry, 42, 710-719.

Hur, Y. M. (2009). Genetic and environmental covariations among obsessive-compulsive symptoms, neuroticism, and extraversion in South Korean adolescent and young adult twins. Twin Research and Human Genetics, 12(2), 142-149.

Hussong, A. M., \& Chassin, L. (1994). The stress-negative affect model of adolescent substance use: Disaggregating negative affect. Journal of Studies on Alcohol, 55, 707-718.

Iacono, W. G., Carlson, S. R., Malone, S. M., \& McGue, M. (2002). P3 event-related potential amplitude and the risk for disinhibitory disorders in adolescent boys Archives of General Psychiatry, 59, 750-757.

Iacono, W. G., \& Malone, S. M. (2011). Developmental Endophenotypes: Indexing Genetic Risk for Substance Abuse with the P300 Brain Event-Related Potential. Child Development Perspectives, 5, 239-247. 
Iacono, W. G., Malone, S. M., \& McGue, M. (2008). Behavioral disinhibition and the development of early-onset addiction: Common and specific influences. Annual Review of Clinical Psychology, 4, 325-348.

Jackson, K. M., \& Sher, K. J. (2003). Alcohol Use Disorders and Psychological Distress: A Prospective State-Trait Analysis. Journal of Abnormal Psychology, 112, 599-613.

Jaffee, S. R., \& Price, T. S. (2007). Gene-environment correlations: a review of the evidence and implications for prevention of mental illness. Molecular Psychiatry, 12, 432-442.

James, L. M., \& Taylor, J. (2007). Impulsivity and negative emotionality associated with substance use problems and Cluster B personality in college students. Addictive Behaviors, 32, 714-727.

Joensuu, M., Lehto, S. M., Tolmunen, T., Saarinen, P. I., Valkonen-Korhonen, M., Vanninen, R., et al. (2010). Serotonin-transporter-linked promoter region polymorphism and serotonin transporter binding in drug-naïve patients with major depression. Psychiatry and Clinical Neurosciences, 64(4), 387-393.

Johnson, E. O., Rhee, S. H., Chase, G. A., \& Breslau, N. (2004). Comorbidity of depression with levels of smoking: An exploration of the shared familial risk hypothesis. Nicotine \& Tobacco Research, 6, 1029-1038.

Kaler, S. R., \& Kopp, C. B. (1990). Compliance and comprehension in very young toddlers. Child Development, 61, 1997-2003.

Karkowski, L. M., Prescott, C. A., \& Kendler, K. S. (2000). Multivariate assessment of factors influencing illicit substance use in twins from female-female pairs. American Journal of Medical Genetics, 96, 665-670. 
Kaslow, N. J., Adamson, L. B., \& Collins, M. H. (2000). A developmental psychopathology perspective on the cognitive components of child and adolescent depression. In A. J. Sameroff, M. Lewis \& S. M. Miller (Eds.), Handbook of Developmental Psychopathology (2nd ed., pp. 491-510). New York: Plenum Publishers.

Kendler, K. S., Aggen, S. H., Tambs, K., \& Reichborn-Kjennerud, T. (2006). Illicit psychoactive substance use, abuse and dependence in population sample of Norwegian twins. Psychological Medicine, 36, 955-962.

Kendler, K. S., \& Gardner, C. O. (2011). A longitudinal etiologic model for symptoms of anxiety and depression in women. Psychological Medicine, 41(10), 2035-2045.

Kendler, K. S., Gardner, C. O., Gatz, M., \& Pedersen, N. L. (2007). The sources of co-morbidity between major depression and generalized anxiety disorder in a Swedish national twin sample. Psychological Medicine, 37, 453-462.

Kendler, K. S., Gardner, C. O., \& Prescott, C. A. (2002). Toward a comprehensive developmental model for major depression in women. American Journal of Psychiatry, $159,1133-1145$.

Kendler, K. S., Gardner, C. O., \& Prescott, C. A. (2006). Toward a comprehensive developmental model for major depression in men. American Journal of Psychiatry, 163, 115-124.

Kendler, K. S., Gatz, M., Gardner, C. O., \& Pedersen, N. L. (2006). Personality and major depression: a Swedish longitudinal, population-based twin study. Archives of General Psychiatry, 63, 1113-1120. 
Kendler, K. S., Heath, A. C., Neale, M. C., Kessler, R. C., \& Eaves, L. J. (1993). Alcoholism and major depression in women: A twin study of the causes of comorbidity. Archives of General Psychiatry, 50, 690-698.

Kendler, K. S., Jacobson, K. C., Prescott, C. A., \& Neale, M. C. (2003). Specificity of genetic and environmental risk factors for use and abuse/dependence of cannabis, cocaine, hallucinogens, sedatives, stimulants, and opiates in male twins. American Journal of Psychiatry, 160, 687-695.

Kendler, K. S., Prescott, C. A., Myers, J., \& Neale, M. C. (2003). The structure of genetic and environmental risk factors for common psychiatric and substance use disorders in men and women. Archives of General Psychiatry, 60, 929-937.

Kensinger, E. A., \& Corkin, S. (2004). Two routes to emotional memory: Distinct neural processes for valence and arousal. Proceedings of the National Academy of Sciences of the United States of America, 101, 3310-3315.

Kessler, R. C., Berglund, P., Demler, O., Jin, R., Koretz, D., Merikangas, K. R., et al. (2003). The epidemiology of major depressive disorder: Results from the National Comorbidity Survey Replication (NCS-R). Journal of the American Medical Association, 289, 30953105.

Kessler, R. C., Berglund, P., Demler, O., Jin, R., \& Walters, E. E. (2005). Lifetime Prevalence and Age-of-Onset Distributions of DSM-IV Disorders in the National Comorbidity Survey Replication. Archives of General Psychiatry, 62, 593-602.

Kessler, R. C., Chiu, W. T., Jin, R., Ruscio, A. M., Shear, K., \& Walters, E. E. (2006). The epidemiology of panic attacks, panic disorder, and agoraphobia in the national comorbidity survey replication. Archives of General Psychiatry, 63, 415-424. 
Keyes, M., Iacono, W. G., \& McGue, M. (2007). Early onset problem behavior, young adult psychopathology, and contextual risk. Twin Research \& Human Genetics, 10, 45-53.

Khan, A. A., Jacobson, K. C., Gardner, C. O., Prescott, C. A., \& Kendler, K. S. (2005). Personality and comorbidity of common psychiatric disorders. British Journal of Clinical Psychology, 186, 190-196.

Kim-Cohen, J., Caspi, A., Moffitt, T. E., Harrington, H., Milne, B. J., \& Poulton, R. (2003). Prior juvenile diagnoses in adults with mental disorder: Developmental follow-back of a prospective-longitudinal cohort. Archives of General Psychiatry, 60, 709-717.

Klein, D. N., Kotov, R., \& Bufferd, S. J. (2011). Personality and depression: Explanatory models and review of the evidence. Annual Review of Clinical Psychology, 7, 269-295.

King, S. M., Iacono, W. G., \& McGue, M. (2004). Childhood externalizing and internalizing psychopathology in the prediction of early substance use. Addiction Biology, 99, 15481559.

Kochanska, G., Barry, R. A., Jimenez, N. B., Hollatz, A. L., \& Woodard, J. (2009). Guilt and effortful control: Two mechanisms that prevent disruptive developmental trajectories. Journal of Personality and Social Psychology, 97(2), 322-333.

Koller, G., Zill, P., Skoruppa, T., Bondy, B., Preuss, U. W., \& Soyka, M. (2008). Low level of harm avoidance is associated with serotonin transporter functional haplotype in alcoholdependent individuals. Psychiatric Genetics, 18, 59-63.

Koob, G. F., Ahmed, S. H., Boutrel, B., Chen, S. A., Kenny, P. J., Markou, A., et al. (2004). Neurobiological mechanisms in the transition from drug use to drug dependence. Neuroscience and Behavioral Review, 27, 739-749. 
Kosten, T. R., George, T. P., \& Kleber, H. D. (2005). The neurobiology of substance dependence: implications for treatment. In R. J. Frances, S. I. Miller \& A. H. Mack (Eds.), Clinical Textbook of Addictive Disorders (pp. 3-15). New York: Guilford.

Kreek, M. J., Nielsen, D. A., Butelman, E. R., \& LaForge, K. S. (2005). Genetic influences on impulsivity, risk taking, stress responsivity and vulnerability to drug abuse and addiction. Nature Neuroscience, 8, 1450-1457.

Krueger, R. F. (1999a). Personality traits in late adolescence predict mental disorders in early adulthood: a prospective-epidemiological study Journal of Personality, 67, 39-65.

Krueger, R. F. (1999b). The structure of common mental disorders. Archives of General Psychiatry, 107, 216-227.

Krueger, R. F., Hicks, B. M., Patrick, C. J., Carlson, S. R., Iacono, W. G., \& McGue, M. (2002). Etiologic connections among substance dependence, antisocial behavior, and personality: modeling the externalizing spectrum. Journal of Abnormal Psychology, 111, 411-424.

Krueger, R. F., \& Markon, K. E. (2006). Reinterpreting comorbidity: A model-based approach to understanding and classifying psychopathology. Annual Review of Clinical Psychology, 2, 111-133.

Krueger, R. F., Markon, K. E., Patrick, C. J., \& Iacono, W. G. (2005). Externalizing psychopathology in adulthood: A dimensional-spectrum conceptualization and its implications for DSM-V. Journal of Abnormal Psychology, 114, 537-550.

Krueger, R. F., McGue, M., \& Iacono, W. G. (2001). The higher-order structure of common DSM mental disorders: internalization, externalization, and their connection to personality. Personality and Individual Differences, 30, 1245-1259. 
Krueger, R. F., \& Piasecki, T. M. (2002). Toward a dimensional and psychometrically-informed approach to conceptualizing psychopathology. Behaviour Research and Therapy, 40, 485-500.

Kunz, J. (2001). Parental divorce and children's interpersonal relationships: A meta-analysis. Journal of Divorce \& Remarriage, 34, 19-47.

Kushner, M. G., Sher, K. J., \& Erickson, D. J. (1999). Prospective Analysis of the Relation Between DSM-III Anxiety Disorders and Alcohol Use Disorders. American Journal of Psychiatry, 156, 723-732.

Lara, D. R., \& Akiskal, H. S. (2006). Toward an integrative model of the spectrum of mood, behavioral and personality disorders based on fear and anger traits: II. Implications for neurobiology, genetics and psychopharmacological treatment. Journal of Affective Disorders, 94, 89-103.

Lara, D. R., Pinto, O., Akiskal, K., \& Akiskal, H. S. (2006). Toward an integrative model of the spectrum of mood, behavioral and personality disorders based on fear and anger traits: I. Clinical implications. Journal of Affective Disorders, 94, 67-87.

Larson, C. L., Nitschke, J. B., \& Davidson, R. J. (2007). Common and distinct patterns of affective response in dimensions of anxiety and depression. Emotion, 7, 182-191.

Lau, J. Y., Rijsdijk, F., \& Eley, T. C. (2006). I think, therefore I am: a twin study of attributional style in adolescents. Journal of Child Psychology and Psychiatry, 47, 696-703.

Legrand, L. N., Keyes, M., McGue, M., Iacono, W. G., \& Krueger, R. F. (2007). Rural environments reduce the genetic influence on adolescent substance use and rule-breaking behavior. Psychological Medicine, 38, 1-10. 
Lenzenweger, M. F., Lane, M. C., Loranger, A. W., \& Kessler, R. C. (2007). DSM-IV personality disorders in the national comorbidity survey replication. Biological Psychiatry, 62, 553-564.

Levinson, D. F. (2006). The Genetics of Depression: A Review. Biological Psychiatry, 60, 8492.

Licht, C. M. M., de Geus, E. J. C., van Dyck, R., \& Penninx, B. W. J. H. (2009). Association between anxiety disorders and heart rate variability in the Netherlands Study of Depression and Anxiety (NESDA). Psychosomatic Medicine, 71(5), 508-518.

Lilienfeld, S. O., Waldman, I. D., \& Israel, A. C. (1994). A critical examination of the use of the term and concept of comorbidity in psychopathology research. Clinical Psychology: Science and Practice, 1, 71-103.

Lonigan, C. J., Carey, M. P., \& Finch, A. J., Jr. (1994). Anxiety and Depression in Children and Adolescents: Negative Affectivity and the Utility of Self-Reports. Journal of Consulting and Clinical Psychology, 62, 1000-1008.

Lonigan, C. J., Phillips, B. M., \& Hooe, E. S. (2003). Relations of positive and negative affectivity to anxiety and depression in children: evidence from a latent variable longitudinal study. Journal of Consulting and Clinical Psychology, 71, 465-481.

Lonigan, C. J., Vasey, M. W., Phillips, B. M., Hazen, R. A., Lonigan, C. J., Vasey, M. W., et al. (2004). Temperament, anxiety, and the processing of threat-relevant stimuli. Journal of Clinical Child \& Adolescent Psychology, 33, 8-20.

Lynskey, M. T., Grant, J. D., Li, L., Nelson, E. C., Bucholz, K. K., \& al., e. (2007). Stimulant use and symptoms of abuse/dependence: epidemiology and associations with cannabis use: A twin study. Drug and Alcohol Dependence, 86, 147-153. 
Markou, A., Kosten, T. R., \& Koob, G. F. (1998). Neurobiological similarities in depression and drug dependence: A self-medication hypothesis. Neuropsychopharmacology, 18, 135174.

Marmorstein, N. R., \& Iacono, W. G. (2011). Explaining associations between cannabis use disorders in adolescence and later major depression: a test of the psychosocial failure model. Addictive Behaviors, 36, 773-776.

Marmorstein, N. R., Iacono, W. G., \& Malone, S. M. (2010). Longitudinal associations between depression and substance dependence from adolescence through early adulthood. Drug \& Alcohol Dependence, 107(2-3), 154-160.

Marshall, P. J., \& Stevenson-Hinde, J. (1998). Behavioral inhibition, heart period, and respiratory sinus arrhythmia in young children. Developmental Psychobiology, 33(3), 283-292. doi: 10.1002/(sici)1098-2302(199811)33:3<283::aid-dev8>3.0.co;2-n

Martin-Soelch, C., Stocklin, M., Dammann, G., Opwis, K., \& Seifritz, E. (2006). Anxiety trait modulates psychophysiological reactions, but not habituation processes related to affective auditory stimuli. International Journal of Psychophysiology, 61, 87-97.

Masse, L. C., \& Tremblay, R. E. (1997). Behavior of boys in kindergarten and the onset of substance use during adolescence. Archives of General Psychiatry, 55, 62-68.

Mathews, A., \& MacLeod, C. (2005). Cognitive vulnerability to emotional disorders. Annual Review of Clinical Psychology, 1(1), 167-195.

McDermott, J. M., Perez-Edgar, K., Henderson, H. A., Chronis-Tuscano, A., Pine, D. S., \& Fox, N. A. (2009). A history of childhood behavioral inhibition and enhanced response monitoring in adolescence are linked to clinical anxiety. Biological Psychiatry, 65(5), 445-448. 
McGue, M., Elkins, I., Walden, B., \& Iacono, W. G. (2005). Perceptions of the parent-adolescent relationship: a longitudinal investigation. Developmental Psychology, 41, 971-984.

McGue, M., \& Iacono, W. G. (2005). The association of early adolescent problem behavior with adult psychopathology. American Journal of Psychiatry, 162, 1118-1124.

McGue, M., Iacono, W. G., \& Krueger, R. F. (2006). The association of early adolescent problem behavior and adult psychopathology: A multivariate behavioral genetic perspective Behavior Genetics, 36, 591-602.

McGue, M., Slutske, W., \& Iacono, W. G. (1999). Personality and substance use disorders: II. Alcoholism versus drug use disorders. Journal of Consulting and Clinical Psychology, $67,2$.

McGue, M., Slutske, W., Taylor, J., \& Iacono, W. G. (1997). Personality and substance use disorders: I. Effects of gender and alcoholism. Alcoholism, Clinical, and Experimental Research, 21, 513-520.

Meehl, P. (2001). Comorbidity and taxometrics. Clinical Psychology: Science and Practice, 8, 507-519.

Merenäkk, L., Mäestu, J., Nordquist, N., Parik, J., Oreland, L., Loit, H.-M., et al. (2011). Effects of the serotonin transporter (5-HTTLPR) and $\alpha[\operatorname{sub}] 2 \mathrm{~A}[/ \mathrm{sub}]$-adrenoceptor $(\mathrm{C}-1291 \mathrm{G})$ genotypes on substance use in children and adolescents: A longitudinal study. Psychopharmacology, 215(1), 13-22.

Merrill, K. A., Steinmetz, J. E., Viken, R. J., \& Rose, R. J. (1999). Genetic influences on human conditionability: A twin study of the conditioned eyeblink response. Behavior Genetics, 29, 95-102. 
Middeldorp, C., Cath, D., Van Dyck, R., \& Boomsma, D. (2005). The co-morbidity of anxiety and depression in the perspective of genetic epidemiology: A review of twin and family studies. Psychological Medicine, 35, 611-624.

Miller, E. K., \& Cohen, J. D. (2001). An integrative theory of prefrontal cortex function. Annual Review of Neuroscience, 24, 167-202.

Miller, M. W., Vogt, D. S., Mozley, S. L., Kaloupek, D. G., \& Keane, T. M. (2006). PTSD and substance-related problems: The mediating roles of disconstraint and negative emotionality. Journal of Abnormal Psychology, 115, 369-379.

Mineka, S., Watson, D., \& Clark, L. A. (1998). Comorbidity of anxiety and unipolar mood disorders. Annual Review of Psychology, 49, 377-412.

Mogg, K., Philippot, P., \& Bradley, B. P. (2004). Selective attention to angry faces in clinical social phobia. Journal of Abnormal Psychology, 113(1), 160-165.

Morgan, B. E., \& Morgan, B. E. (2006). Behavioral inhibition: a neurobiological perspective. Current Psychiatry Reports, 8, 270-278.

Murisa, P., Meesters, C., \& Blijlevens, P. (2007). Self-reported reactive and regulative temperament in early adolescence: Relations to internalizing and externalizing problem behavior and "Big Three”, personality factors. Journal of Adolescence, 3, 1035-1049.

Muris, P., Meesters, C., Merckelbach, H., Sermon, A., \& Zwakhalen, S. (1998). Worry in normal children. Journal of the American Academy of Child and Adolescent Psychiatry, 37, 703710.

Muris, P., \& Ollendick, T. H. (2005). The role of temperament in the etiology of child psychopathology. Clinical Child and Family Psychology Review, 8, 271-289. 
Myrick, H. \& Brady, K. (2003). Current review of the comorbidity of affective, anxiety, and substance use disorders. Current Opinions in Psychiatry, 16, 261-270.

Nadder, T. S., Rutter, M., Silberg, J. L., Maes, H. H., \& Eaves, L. J. (2002). Genetic effects on the variation and covariation of attention deficit-hyperactivity disorder (ADHD) and oppositional-defiant disorder/conduct disorder (ODD/CD) symptomatologies across informant and occasion of measurement. Psychological Medicine, 32, 39-53

Nemeroff, C. B., \& Vale, W. W. (2005). The neurobiology of depression: Inroads to treatment and new drug discovery. The Journal of clinical psychiatry, 66, 5-13.

Nestler, E. J. (2005). Is there a common molecular pathway for addiction? Nature Neuroscience, 8, 1445-1449.

Nock, M. K., Kazdin, A. E., Hiripi, E., \& Kessler, R. C. (2006). Prevalence, subtypes, and correlates of DSM-IV conduct disorder in the National Comorbidity Survey Replication. Psychological Medicine, 36, 699-710.

Nolen-Hoeksema, S., Girgus, J. S., \& Seligman, M. E. (1992). Predictors and consequences of childhood depressive symptoms: A 5-year longitudinal study. Journal of Abnormal Psychology, 101, 405-422.

Nolen-Hoeksema, S., Wisco, B. E., \& Lyubomirsky, S. (2008). Rethinking rumination. Perspectives on Psychological Science, 3(5), 400-424.

Nutt, D., Argyropoulos, S., Hood, S., \& Potokar, J. (2006). Generalized anxiety disorder: A comorbid disease. European Neuropsychopharmacology, 16, S109-S118.

Oldehinkel, A. J., Hartman, C. A., Ferdinand, R. F., Verhulst, F. C., \& Ormel, J. (2007). Effortful control as modifier of the association between negative emotionality and adolescents' mental health problems. Development and Psychopathology, 19, 523-539. 
Oldehinkel, A. J., Hartman, C. A., Winter, A. F., Veenstra, R., \& Johan, O. (2004).

Temperament profiles associated with internalizing and externalizing problems in preadolescence. Development and Psychopathology, 16, 421-440.

Ormel, J., Oldehinkel, A. J., Ferdinand, R. F., Hartman, C. A., De Winter, A. F., Veenstra, R., et al. (2005). Internalizing and externalizing problems in adolescence: general and dimension-specific effects of familial loadings and preadolescent temperament traits. Psychological Medicine, 35, 1825-1835.

Papageorgiou, C. (2006). Worry and Rumination: Styles of Persistent Negative Thinking in Anxiety and Depression. In G. C. L. Davey \& A. Wells (Eds.), Worry and its psychological disorders: Theory, assessment and treatment (pp. 21-40). Hoboken, NJ: Wiley Publishing.

Papiol, S., Arias, B., Gasto, C., Gutierrez, B., Catalan, R., \& Fananas, L. (2007). Genetic variability at HPA axis in major depression and clinical response to antidepressant treatment. Journal of Affective Disorders, 104, 83-90.

Pardini, D., Lochman, J., \& Wells, K. (2004). Negative Emotions and Alcohol Use Initiation in High-Risk Boys: The Moderating Effect of Good Inhibitory Control. Journal of Abnormal Child Psychology, 32, 505-518.

Patrick, C. J. (2006). The construct of emotion as a bridge between personality and psychopathology. In R. F. Krueger \& J. Tackett (Eds.), Personality and Psychopathology (pp. 174-209). New York: Guilford.

Pedlow, R., Sanson, A., Prior, M., \& Oberklaid, F. (1993). Stability of maternally reported temperament from infancy to 8 years. Developmental Psychology, 29, 998-1007. 
Pérez-Edgar, K., Reeb-Sutherland, B. C., McDermott, J. M., White, L. K., Henderson, H. A., Degnan, K. A., et al. (2011). Attention biases to threat link behavioral inhibition to social withdrawal over time in very young children. Journal of Abnormal Child Psychology, 39(6), 885-895.

Perlman, G., Johnson, W., \& Iacono, W. G. (2009). The heritability of P300 amplitude in 18year-olds is robust to adolescent alcohol use. Psychophysiology, 46, 962-969.

Perlman, G., Markin, A., \& Iacono, W.G. (2013). P300 amplitude reduction is associated with early-onset and late-onset pathological substance use in a prospectively studied cohort of 14 year-old adolescents. Psychophysiology, In Press.

Plomin, R., \& Bergeman, C. S. (1991). The nature of nurture: genetic influence on “environmental” measures. Behavior and Brain Sciences, 14, 373-427.

Porges, S. W. (2011). The polyvagal theory: Neurophysiological foundations of emotions, attachment, communication, and self-regulation. New York, NY US: W W Norton \& Co.

Porter, R. J., Gallagher, P., Watson, S., Young, A. H., Porter, R. J., Gallagher, P., et al. (2004). Corticosteroid-serotonin interactions in depression: a review of the human evidence. Psychopharmacology, 173, 1-17.

Prescott, C. A., Aggen, S. H., \& Kendler, K. S. (2000). Sex-specific genetic influences on the comorbidity of alcoholism and major depression in a population-based sample of US twins. Archives of General Psychiatry, 57, 803-811.

Rao, U., Daley, S. E., \& Hammen, C. (2000). Relationship between depression and substance use disorders in adolescent women during the transition to adulthood. Journal of the American Academy of Child \& Adolescent Psychiatry, 39, 215-222. 
Regier, D. A., Farmer, M. E., Rae, D. S., Locke, B. Z., Keith, S. J., Judd, L. L., et al. (1990). Comorbidity of mental disorders with alcohol and other drug abuse. Results from the Epidemiologic Catchment Area (ECA) Study. Journal of the American Medical Association, 264, 2511-2518.

Rice, F., van den Bree, M. B., Thapar, A., Rice, F., van den Bree, M. B. M., \& Thapar, A. (2004). A population-based study of anxiety as a precursor for depression in childhood and adolescence. BMC Psychiatry, 4, 43.

Risbrough, V. B., \& Stein, M. B. (2006). Role of corticotropin releasing factor in anxiety disorders: A translational research perspective. Hormones and Behavior, 50, 550-561.

Roberts, B. W., \& DelVecchio, W. F. (2000). The rank-order consistency of personality traits from childhood to old age: A quantitative review of longitudinal studies. Psychological Bulletin, 126, 3-25.

Rose, R. J., Dick, D. M., Viken, R. J., \& Kaprio, J. (2001). Gene-environment interaction in patterns of adolescent drinking: regional residencey moderates longitudinal influences on alcohol use. Alcoholism: Clinical \& Experimental Research, 25, 637-643.

Rothbart, M. K. (1989). Temperament and development. In J. E. Kohnstamm, J. E. Bates \& M. K. Rothbart (Eds.), Temperament in Childhood (pp. 187-247). New York: Wiley.

Rothbart, M. K., Ahadi, S. A., \& Evans, D. E. (2000). Temperament and personality: Origins and outcomes. Journal of Personality and Social Psychology, 78, 122-135.

Rothbart, M. K., Ahadi, S. A., \& Hershey, K. L. (1994). Temperament and social behavior in childhood. Merrill-Palmer Quarterly, 40, 21-39. 
Rothbart, M. K., Posner, M. I., \& Hershey, K. L. (1995). Temperament, attention, and developmental psychology. In D. Cicchetti \& D. J. Cohen (Eds.), Developmental psychopathology: Vol 1. Theory and methods (pp. 315-340). New York: Wiley.

Rothbart, M. K., Posner, M. I., \& Rosicky, J. (1994). Orienting in normal and pathological development. Development and Psychopathology, 6, 635-652.

Rounsaville, B. J. (2004). Treatment of cocaine dependence and depression. Biological Psychiatry, 56, 803-809.

Ruscio, A. M., Chiu, W. T., Roy-Byrne, P., Stang, P. E., Stein, D. J., Wittchen, H. U., et al. (2007). Broadening the definition of generalized anxiety disorder: Effects on prevalence and associations with other disorders in the National Comorbidity Survey Replication. Journal of Anxiety Disorders, 21, 662-676.

Rutter, M., \& Silberg, J. (2002). Gene-environment interplay in relation to emotional and behavioral disturbance. Annual Review of Clinical Psychology, 53, 463-490.

Sarosi, A., Gonda, X., Balogh, G., Domotor, E., Szekely, A., Hejjas, K., et al. (2008). Association of the STin2 polymorphism of the serotonin transporter gene with a neurocognitive endophenotype in major depressive disorder. Progress in NeuroPsychopharmacology \& Biological Psychiatry, 32, 1667-1672.

Seligman, M. E. P. (1974). Depression and learned helplessness. In R. J. Friedman \& M. Katz (Eds.), The psychology of depression: Contemporary theory and research (pp. 83-113). Washington, D.C.: Winston.

Sharma, R. K., Balhara, Y. P. S., Sagar, R., Deepak, K. K., \& Mehta, M. (2011). Heart rate variability study of childhood anxiety disorders. Journal of Cardiovascular Disease Research, 2(2), 115-122. 
Sher, K. J., Bartholow, B. D., \& Wood, M. D. (2000). Personality and substance use disorders: A prospective study. Journal of Consulting and Clinical Psychology, 68, 818-829.

Silberg, J., Rutter, M., Meyer, J., Maes, H., Hewitt, J., \& Simonoff, E., et al. (1996). Genetic and environmental influences on covariation between hyperactivity and conduct disturbance in juvenile twins. Journal of Child Psychology \& Psychiatry \& Allied Disciplines, 37, 803-816.

Silk, J. S., Steinberg, L., \& Morris, A. S. (2003). Adolescents' emotion regulation in daily life: Links to depressive symptoms and problem behavior. Child Development, 74, 1869-1880.

Slutske, W. S., Heath, A. C., Madden, P. A., Bucholz, K. K., Statham, D. J., \& Martin, N. G. (2002). Personality and the genetic risk for alcohol dependence. Journal of Abnormal Psychology, 111, 124-133.

Spengler, M., Gottschling, J., \& Spinath, F. M. (2012). Personality in childhood-A longitudinal behavior genetic approach. Personality and Individual Differences, 53(4), 411-416.

Spitzer, R. L. (1994). Psychiatric "co-occurrence"? I'll stick with "comorbidity". Clinical Psychology: Science and Practice, 1, 88-92.

Stein, M. B., Jang, K. L., \& Livesley, W. J. (1999). Heritability of Anxiety Sensitivity: A Twin Study. American Journal of Psychiatry, 156, 246-251.

Stockdale, S. E., Wells, K. B., Tang, L., Belin, T. R., Zhang, L., Sherbourne, C. D., et al. (2007). The importance of social context: neighborhood stressors, stress-buffering mechanisms, and alcohol, drug, and mental health disorders. Social Science \& Medicine, 65, 18671881.

Sullivan, P. F., Neale, M. C., \& Kendler, K. S. (2000). Genetic epidemiology of major depression: Review and meta-analysis. American Journal of Psychiatry, 157, 1552-1562. 
Swan, G. E., Carmelli, D., \& Cardon, L. R. (1996). The consumption of tobacco, alcohol, and office in Caucasian male twins: A mulivariate genetic analysis. Journal of Substance Abuse, 8, 19-31.

Tafet, G. E., Feder, D. J., Abulafia, D. P., \& Roffman, S. S. (2005). Regulation of hypothalamicpituitary-adrenal activity in response to cognitive therapy in patients with generalized anxiety disorder. Cognitive, Affective \& Behavioral Neuroscience, 5, 37-40.

Tarantino, N. Tully, E.C., Garcia, S., South, S., Iacono, W.G., \& McGue, M. (2014). Genetic and environmental influences on affiliation with deviant peers during adolescence and early adulthood. Developmental Psychology, 50, 663-673.

Tarter, R. E., Blacksona, T., Brighama, J., Mossa, H., \& Caprarab, G. V. (1995). The association between childhood irritability and liability to substance use in early adolescence: a 2-year follow-up study of boys at risk for substance abuse Drug and Alcohol Dependence 39, 253-261.

Taylor, J., Reeves, M., James, L., \& Bobadilla, L. (2006). Disinhibitory Trait Profile and Its Relation to Cluster B Personality Disorder Features and Substance Use Problems. European Journal of Personality, 20, 271-284.

Tellegen, A. (1982). Brief manual for the multidimensional personality questionnaire. University of Minnesota, Minneapolis: Unpublished manuscript.

True, W. R., Heath, A. C., Scherrer, J. F., Xian, H., Lin, N., \& al., e. (1999). Interrelationship of genetic and environmental influences on conduct disorder and alcohol and marijuana dependence symptoms. American Journal of Medical Genetics, 88, 391-387. 
True, W. R., Xian, H., Scherrer, J. F., Madden, P. A., Bucholz, K. K., \& al., e. (1999). Common genetic vulnerability for nicotine and alcohol dependence in men. Archives of General Psychiatry, 56, 655-661.

Tsuang, M. T., Lyons, M. J., Meyer, J. M., Doyle, T., Eisen, S. A., \& al., e. (1998). Cooccurrence of abuse of different drugs in men: Teh role of drug-specific and shared vulnerabilities. Archives of General Psychiatry, 55, 967-972.

Tully, E. C., Iacono, W. G., \& McGue, M. (2010). Changes in genetic and environmental influences on the development of nicotine dependence and major depressive disorder from middle adolescence to early adulthood. Development and Psychopathology, 22, 831-848.

Trzaskowski, M., Zavos, H. M. S., Haworth, C. M. A., Plomin, R., \& Eley, T. C. (2012). Stable genetic influence on anxiety-related behaviours across middle childhood. Journal of Abnormal Child Psychology, 40(1), 85-94.

Turner, J. E., \& Cole, D. A. (1994). Development differences in cognitive diatheses for child depression. Journal of Abnormal Child Psychology, 22, 15-32.

Vaidyanathan, U., Patrick, C. J., \& Cuthbert, B. N. (2009). Linking dimensional models of internalizing psychopathology to neurobiological systems: affect-modulated startle as an indicator of fear and distress disorders and affiliated traits. Psychological Bulletin, 135, 909-942.

Valdez, A., Kaplan, C. D., \& Curtis, R. L., Jr. (2007). Aggressive crime, alcohol and drug use, and concentrated poverty in 24 U.S. urban areas. American Journal of Drug and Alcohol Abuse, 33, 595-603. 
van Beijsterveldt, C. E., \& van Baal, G. C. (2002). Twin and family studies of the human electroencephalogram: a review and a meta-analysis. Bioligical Psychology, 61, 111-138.

Vanderhasselt, M. A., De Raedt, R., Dillon, D. G., Dutra, S. J., Brooks, N., \& Pizzagalli, D. A. (2012). Decreased cognitive control in response to negative information in patients with remitted depression: An event-related potential study. Journal of Psychiatry \& Neuroscience, 37(4), 250-258.

Vrieze, S., Hicks, B. M., Iacono, W G, \& McGue, M. (2012). Decline in genetic influence on the co-occurrence of alcohol, marijuana, and nicotine dependence symptoms from age 14 to 29. American Journal of Psychiatry, 169, 1073-1081.

Wardenaar, K. J., Vreeburg, S. A., van Veen, T., Giltay, E. J., Veen, G., Penninx, B. W. J. H., et al. (2011). Dimensions of depression and anxiety and the hypothalamo-pituitary-adrenal axis. Biological Psychiatry, 69(4), 366-373.

Wang, J. C., Hinrichs, A. L., Stock, H., Budde, J., Allen, R., Bertelsen, S., et al. (2004). Evidence of common and specific genetic effects: association of the muscarinic acetylcholine receptor M2 (CHRM2) gene with alcohol dependence and major depressive syndrome. Human Molecular Genetics, 13, 1903-1911.

Watson, D. (2005). Rethinking the mood and anxiety disorders: A quantitative hierarchical model for DSM-V. Journal of Abnormal Psychology, 114, 522-536.

Weinberg, N. Z., Rahdert, E., Colliver, J. D., \& Glantz, M. D. (1998). Adolescent substance abuse: A review of the past 10 years. American Academy of Child and Adolescent Psychiatry, 37, 252-261. 
Wilson, S., DiRago, A.C., \& Iacono, W.G. (2014). Prospective interrelationship between late adoelscent personality and major depressive disorder in early adulthood. Psychological Medicine, 44(3), 567-577.

Wong, M. M., Nigg, J. T., Zucker, R. A., Puttler, L. I., Fitzgerald, H. E., \& al., e. (2006). Behavioral control and resiliency in the onset of alcohol and illicit drug use: A prospective study from preschool to adolescence. Child Development, 77, 1016-1033.

Woodward, L. J., \& Fergusson, D. M. (2001). Life course outcomes of young people with anxiety disorders in adolescence. Journal of the American Academy of Child Adolescent Psychiatry 40, 1086-1093.

Yoon, H., Iacono, W. G., Malone, S., \& McGue, M. (2006). Using the brain P300 response to identify novel phenotypes reflecting genetic vulnerability for adolescent substance misuse. Addictive Behaviors, 31, 1067-1087.

Young, S. E., Friedman, N. P., Miyake, A., Willcutt, E. G., Corley, R. P., Haberstick, B. C., et al. (2009). Behavioral disinhibition: Liability for externalizing spectrum disorders and its genetic and environmental relation to response inhibition across adolescence. Journal of Abnormal Psychology, 118(1), 117-130.

Young, S. E., Stallings, M. C., Corley, R. P., Krauter, K. S., \& Hewitt, J. K. (2000). Genetic and environmental influences on behavioral disinhibition. American Journal of Medical Genetics, 96, 684-695.

Zai, C. C., Ehtesham, S., Choi, E., Nowrouzi, B., de Luca, V., Stankovich, L., et al. (2012). Dopaminergic system genes in childhood aggression: Possible role for DRD2. The World Journal of Biological Psychiatry, 13(1), 65-74. 
Zetsche, U., D'Avanzato, C., \& Joormann, J. (2012). Depression and rumination: Relation to components of inhibition. Cognition and Emotion, 26(4), 758-767.

Zinbarg, R. E., \& Barlow, D. H. (1996). Structure of anxiety and the anxiety disorders: A hierarchical model. Journal of Abnormal Psychology, 105, 181-193.Zoltgn, S., Biro, Eva, Gardi, J., Vecsernyds, M., Julesz, J., \& Telegdy, G. (1995). Brain corticotropin-releasing factor mediates 'anxiety-like' behavior induced by cocaine withdrawal in rats. Brain Research, 675, 89-97. 


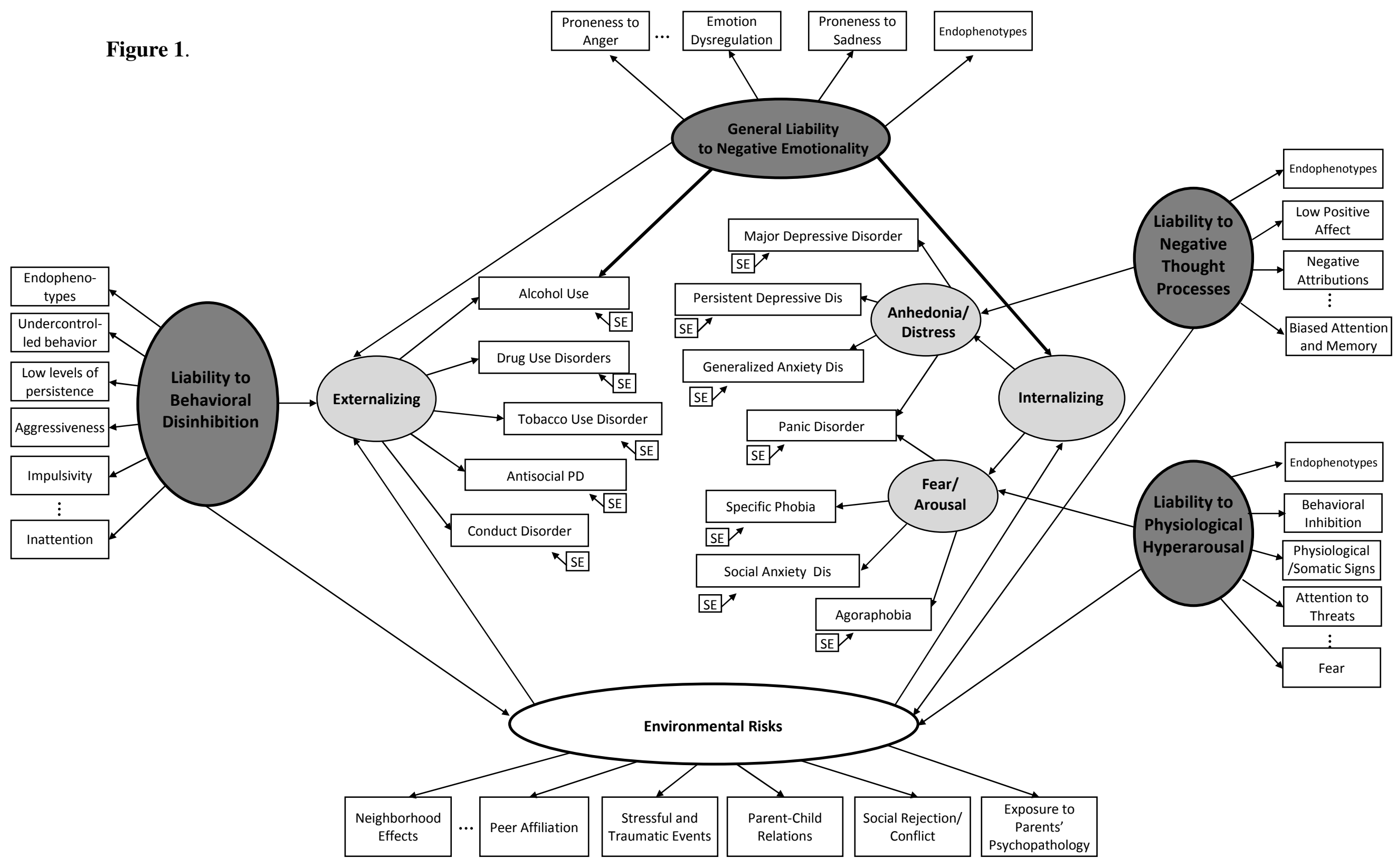




\section{Figure Caption}

An integrative model that explains comorbidity among substance use disorders and other common mental disorders through a hierarchical structure of general and disorder-specific genetic and environmental effects. A broad externalizing factor represents the covariance among conduct disorder, antisocial personality disorder, tobacco use disorder, drug use disorders, and alcohol use disorder, and a broad internalizing factor represents the covariance among depressive and anxiety disorders. The internalizing factor is further divided into two subfactors: (1) an anhedonia/misery factor that represents the covariance among major depressive disorder, persistent depressive disorder, and generalized anxiety disorder; and (2) a fear/arousal factor that represents the covariance among specific phobia, social anxiety disorder, and agoraphobia. Panic disorder loads onto both internalizing subfactors. These internalizing and externalizing factors derive from genetically influenced biological predispositions/liabilities, each of which is expressed as a spectrum of related personality traits, cognitive processes, and behavioral tendencies. At the highest level of the hierarchy, a liability to negative emotionality (NE; proneness to experiencing negative emotions, tendency toward dysregulation) influences risk for both externalizing and internalizing disorders. The NE liability has particularly strong loadings (bold lines) on the internalizing factor and on alcohol use disorders and thus is a substantial contributor to comorbidity among internalizing disorders, as well as between internalizing disorders and alcohol use disorders. Negative emotionality has a smaller effect on comorbidity between INT disorders and other externalizing disorders. At the next level of the hierarchy, a liability to behavioral disinhibition (BD; undercontrolled behavior, low levels of persistence, aggressiveness, impulsivity, inattention) underlies risk for disorders in the externalizing factor. A liability to negative thought processes (NT processes; low positive affect, habitual negative 
attributions and expectations, biased attention and memory, worry, rumination) contributes to risk for the anhedonia/misery disorders. A liability to physiological arousal (PH;

psychophysiological/somatic signs, fear, heightened attention to threats, behavioral inhibition) influences risk for fear/arousal disorders. Environmental risks are influenced by the genetic liabilities (e.g., BD contributes to affiliation with deviant peers) and also contribute to the etiology of internalizing and externalizing disorders. Some environmental factors (e.g., stressful and traumatic events, negative parent-child relations, exposure to parents' psychopathology) contribute to risk for both externalizing and internalizing disorders, whereas other environmental factors are likely to have a greater influence on either the externalizing factor (e.g., neighborhood crime and availability of substances, deviant peer affiliation) or the internalizing factor (e.g., social rejection, peer conflict). At the lowest level of the hierarchy, unique genetic and environmental risks specific to each disorder (SE; specific effects) explain why individuals with the same general liability do not all have the same outcomes. The cumulative effects of geneenvironment interplay across development lead to the emergence of mental disorders, and the hierarchical structure of genetically influenced liabilities contributes to covariance among disorders and the observed pattern of comorbidity. 